\title{
Closing the Gap: Sustainable Intensification Implications of Increased Corn Yields and Quality for Second-Crop (Safrinha) in Mato Grosso, Brazil
}

\author{
Daniel T. Pinheiro ${ }^{1,2} \mathbb{D}$, Diego M. S. Santos ${ }^{1}$, Alan R. R. Martins ${ }^{1}$, Wininton M. da Silva ${ }^{3} \mathbb{D}$, \\ Cláudio V. de Araújo ${ }^{2}$, Daniel C. de Abreu 1,2,*(D), Aaron Kinyu Hoshide ${ }^{4}$ (D) Luana Molossi ${ }^{1}$ \\ and Ronaldo A. de Oliveira ${ }^{1}$
}

check for updates

Citation: Pinheiro, D.T.; Santos, D.M.S.; Martins, A.R.R.; da Silva, W.M.; de Araújo, C.V.; de Abreu, D.C.; Hoshide, A.K.; Molossi, L.; de Oliveira, R.A. Closing the Gap: Sustainable Intensification Implications of Increased Corn Yields and Quality for Second-Crop (Safrinha) in Mato Grosso, Brazil. Sustainability 2021, 13, 13325. https://doi.org/10.3390/ su132313325

Academic Editor: Sean Clark

Received: 16 October 2021

Accepted: 26 November 2021

Published: 1 December 2021

Publisher's Note: MDPI stays neutral with regard to jurisdictional claims in published maps and institutional affiliations.

Copyright: (c) 2021 by the authors. Licensee MDPI, Basel, Switzerland. This article is an open access article distributed under the terms and conditions of the Creative Commons Attribution (CC BY) license (https:/ / creativecommons.org/licenses/by/ $4.0 /)$.
1 AgriSciences, Universidade Federal de Mato Grosso, Caixa Postal 729, Sinop 78550-970, MT, Brazil daniel.pinheiro@agrisciences.org (D.T.P.); diego.magalhaes@ufv.br (D.M.S.S.); alan.martins@agrisciences.org (A.R.R.M.); luana.molossi@agrisciences.org (L.M.); ronaldo.oliveira@agrisciences.org (R.A.d.O.)

2 Instituto de Ciências Agrárias e Ambientais (ICAA), Universidade Federal do Mato Grosso, Campus Universitário de Sinop, Avenida Alexandre Ferronato, 1200, Sinop 78550-728, MT, Brazil; cvaufmt@gmail.com

3 Empresa Mato-Grossense de Pesquisa, Assistência e Extensão Rural (EMPAER-MT), Centro Político Administrativo, Cuiabá 78049-903, MT, Brazil; winintonsilva@empaer.mt.gov.br

4 College of Natural Sciences, Forestry and Agriculture, The University of Maine, Orono, ME 04469, USA; aaron.hoshide@maine.edu

* Correspondence: abreu@ufmt.br; Tel.: +55-66-3515-8574

Abstract: Corn grown as second-crop (safrinha) immediately after soybeans contributes to Brazil's recent sustainable intensification of efforts to land spare and reduce deforestation. Brazil's Mato Grosso state is very important for corn production with a large number of available hybrids for producers with different characteristics. Evaluating as many hybrids as possible increases the likelihood of identifying those that are more productive. Our experiment used a randomized block design to evaluate 20 corn hybrids for yield and quality in the western Cerrado savannah region of Mato Grosso state. There were significant differences in silage quality and grain yield between hybrids. Silage quality was correlated with higher grain yield. Corn grain yields for 10 higher-yielding hybrids (average $=11,425 \mathrm{~kg} /$ hectare) were significantly greater than the two lowest yielding hybrids (6974 and $8207 \mathrm{~kg} /$ hectare) and 64\% more than the 2020 average in Mato Grosso. Precipitation was not limiting during our experiment but may be in the drier Cerrado area and during other years. Higher silage quality with lower lignin content and higher in vitro digestibility can improve beef productivity as Brazil transitions from extensive grazing to more intensified systems such as pasture supplementation. Increasing corn grain yields in Mato Grosso can hedge against lower crop yields elsewhere.

Keywords: Cerrado; crop yield; grain; livestock feed; quality; second-crop; silage; sustainable intensification; yield; Zea mays L.

\section{Introduction}

Corn (Zea mays L.) is one of the most important crops grown worldwide, with a total production of 1163.21 billion tons [1]. Brazil is one of the world's biggest corn producers, with Mato Grosso state producing about 33 million tons per year [2]. Mato Grosso is part of the Cerrado savannah biome in Brazil. The Cerrado is characterized by low land prices and favorable climate and topography. This has driven agricultural expansion here, including cattle, swine, and poultry, over the last four decades. Livestock has expanded in the Cerrado more so than in the rest of Brazil. Annual crop production in the Cerrado accounts for $40 \%$ of Brazil's total crop production [3]. Corn's importance goes beyond its 
contribution to Brazil's economy, and includes nutritional value in human food and use for animal feed either as concentrated grain or bulk ensiled forage (i.e., silage) and for fuel as ethanol. Thus, corn is one of the best options for both silage and grain production since it has good nutritional value, a large amount of energy, high starch content, the potential for high dry matter production per hectare, low production cost, and ease of harvesting. In addition, a large number of cultivars are adapted to different climates, and it is a traditionally grown species, widespread in rural areas [4-10].

Recent transition in Brazil to more intensified back-to-back cropping of (1) soybeans with corn or (2) soybeans with cotton along with agricultural expansion has almost doubled intensive row crops from 2000 to 2014 [11]. Corn in Brazil's Amazon, Cerrado, and Atlantic Forest biomes has shifted from being primarily grown during the wet season (October to February) to being grown as a second crop (safrinha) during the dry season (March to June) following soybeans. Soybeans have increasingly replaced corn during the wet season as a first-crop (safra) to avoid yield loss if grown during the dry season. From 2003-2016, Brazil's total corn grown as safrinha increased from 26.3 to $66.6 \%$ of total corn area, with safrinha surpassing safra in 2012 [12]. Over the last decade, dry-season corn increased from 34 to $73 \%$ of total corn [13]. Corn grown during the first-crop (safra) wet season around the same time as soybeans is more common in regions in the eastern Cerrado. There is not enough annual rainfall for both crops in eastern Matopiba (Maranhão, Tocatins, southern Piauí, and western Bahia states; Figure 1) [14]. Matopiba has been at the forefront of Brazil's recent agricultural expansion [15].

The use of corn as animal feed has been essential for improved productivity. Livestock intensification has increasingly required the use of technologies that allow efficiency and economy in animal production. This has highlighted the importance of balancing productivity gains with the higher cost of inputs used such as corn silage and grain feed. Grains are predominant components in cattle diets, and the degree of processing and the species in question influence their digestion by ruminants. When considering not only the grain itself but also a better use of forages, silage is seen as an accessory tool to maintain animal production, especially in periods when there is a shortage of green forage [9,16-18]. The excellent forage resource offered by corn is related to its production of excellent quality forage biomass, with high digestibility and energy values [19]. Studies evaluating grain yield and corn silage quality have been reported based on several other factors, such as soil fertility [20,21], intercropping with other species [22], and harvest periods [23].

According to [24], strong interest in corn hybrids and breeding methods captivated the plant breeding community during the 1920s and 1930s because of the extensive number of breeding programs and the new type of cultivars (e.g., hybrids) for corn producers. Considering the importance of Mato Grosso for corn production in Brazil, there is a large number of corn hybrids available to producers with different characteristics. It is often difficult for corn producers to select which hybrid will be the most suitable to meet productivity expectations. In this context, the more hybrids that are evaluated, the more likely there will be better choices for producers. Moreover, there is constant interaction between genotype and environment in cropping systems. This influences which crop cultivars used for ensiled forage and grain production are better suited for the specific meteorological and soil conditions of each location. Therefore, given the role of corn in meat and milk production systems, choosing the most suitable hybrids for the production of silage and grain is extremely important, while also considering the productive potential of each hybrid and the agronomic characteristics of plants [8,25]. Along with the aforementioned characteristics, the chemical composition and the quality of silage and grain should also be evaluated. Such quality is influenced by genetics, maturation stage at harvest, soil and climate [26]. 


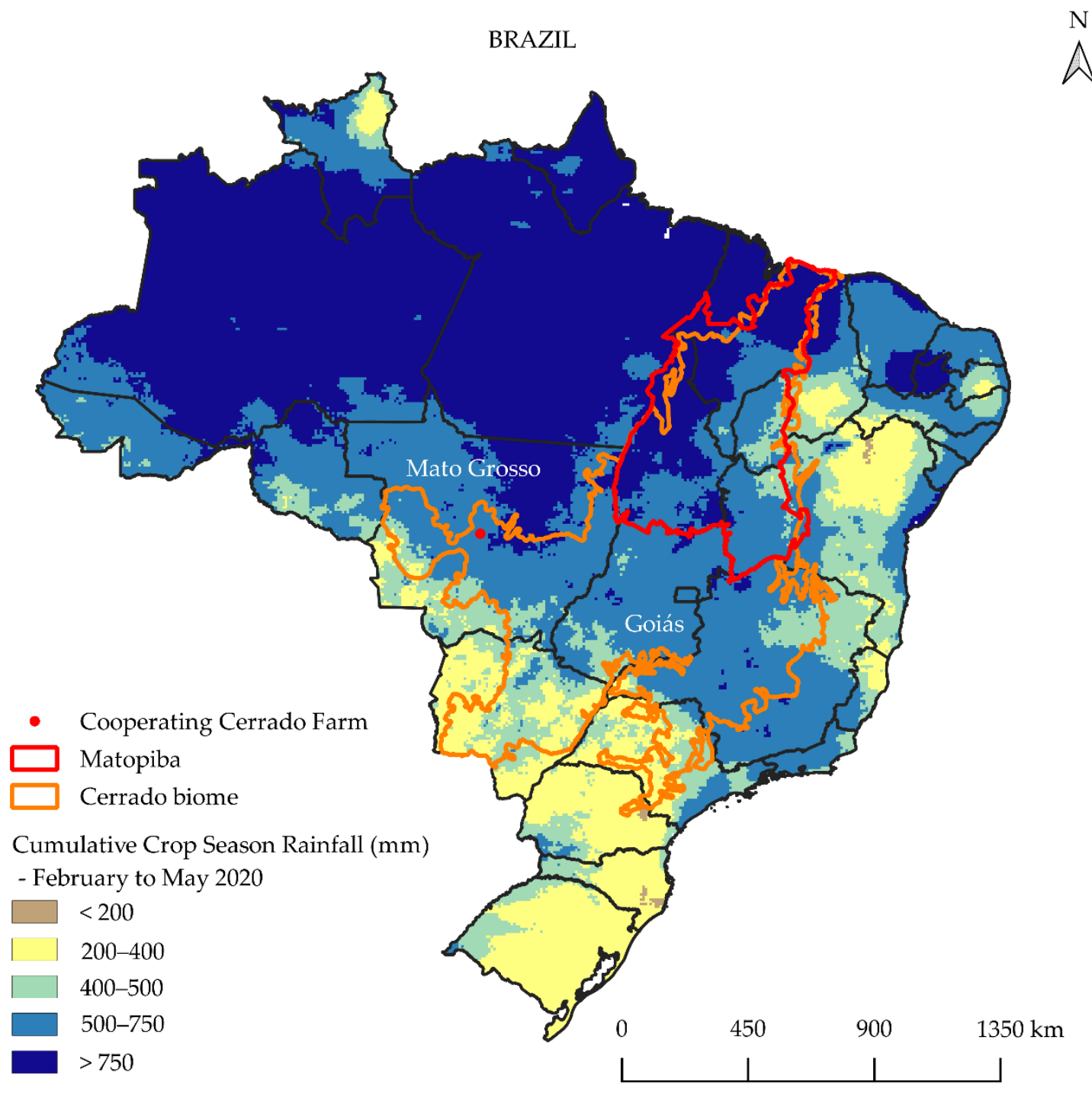

Figure 1. Brazil accumulated precipitation (mm) from February to May 2020 (200, 400, 500, and 750 mm boundaries).

Recent studies have considered genetics in evaluating the yield and quality of corn grown under different conditions. Potential hybrids for grain and silage production were selected from 72 corn strains in the state of Paraná in southern Brazil [10]. Morphoagronomic and bromatological characteristics were evaluated for 19 corn hybrids for silage in Rio de Janeiro state in southeast Brazil, with positive associations between dry matter yields and silage quality [27]. In Ethiopia, Africa, corn hybrids had better combined food-fodder traits [28]. The evaluation of different corn hybrids is also reported to be important for the selection of genetic materials in different organic systems [29]. Based on these studies, the evaluation of at least 20 corn hybrids seems to be adequate for genetic selection for this crop. Therefore, studies evaluating different hybrids in Mato Grosso (MT) state are scarce and important for the achievement of increasingly productive and sustainable agricultural systems in this increasingly important agricultural region in Brazil.

In light of the above, the objectives of this study were to (1) evaluate 20 corn hybrids for agronomic characteristics and bromatological composition of both ensiled forage and grain and (2) determine potential sustainable intensification benefits of improving corn hybrid silage and grain production. Our research could improve corn hybrid selection for silage for Nelore beef (Bos indicus) feedlot finishing. It could also assure adequate corn grain production in Brazil for commodity exports, supplementation of pasture-based beef, 
and to support more diversified cropping systems such as those integrating agro-forestry that take yield penalties for corn.

\section{Materials and Methods}

\subsection{Mapping}

Precipitation maps for February to May 2020 (Figures 1 and A1-A4, Appendix A) and a Cerrado biome and experimental location map (Figure 2) were created using QGIS 3.16.10 software (https://qgis.org/en/site/, accessed on 2 September 2021), an opensource geographic information system (GIS) licensed under a public license, used for delineating the area of interest in the Cerrado biome, classification of accumulated precipitation, and map construction. QGIS is an official project developed by the Open-Source Geospatial Foundation (OSGeo). Raster data files (geotiff format, $0.1^{\circ} \times 0.1^{\circ}$ resolution) of total monthly rainfall (February to May 2020) for Brazil were downloaded from the Giovanni online data system version 4.35 maintained by the National Aeronautics and Space Administration (NASA) [30].

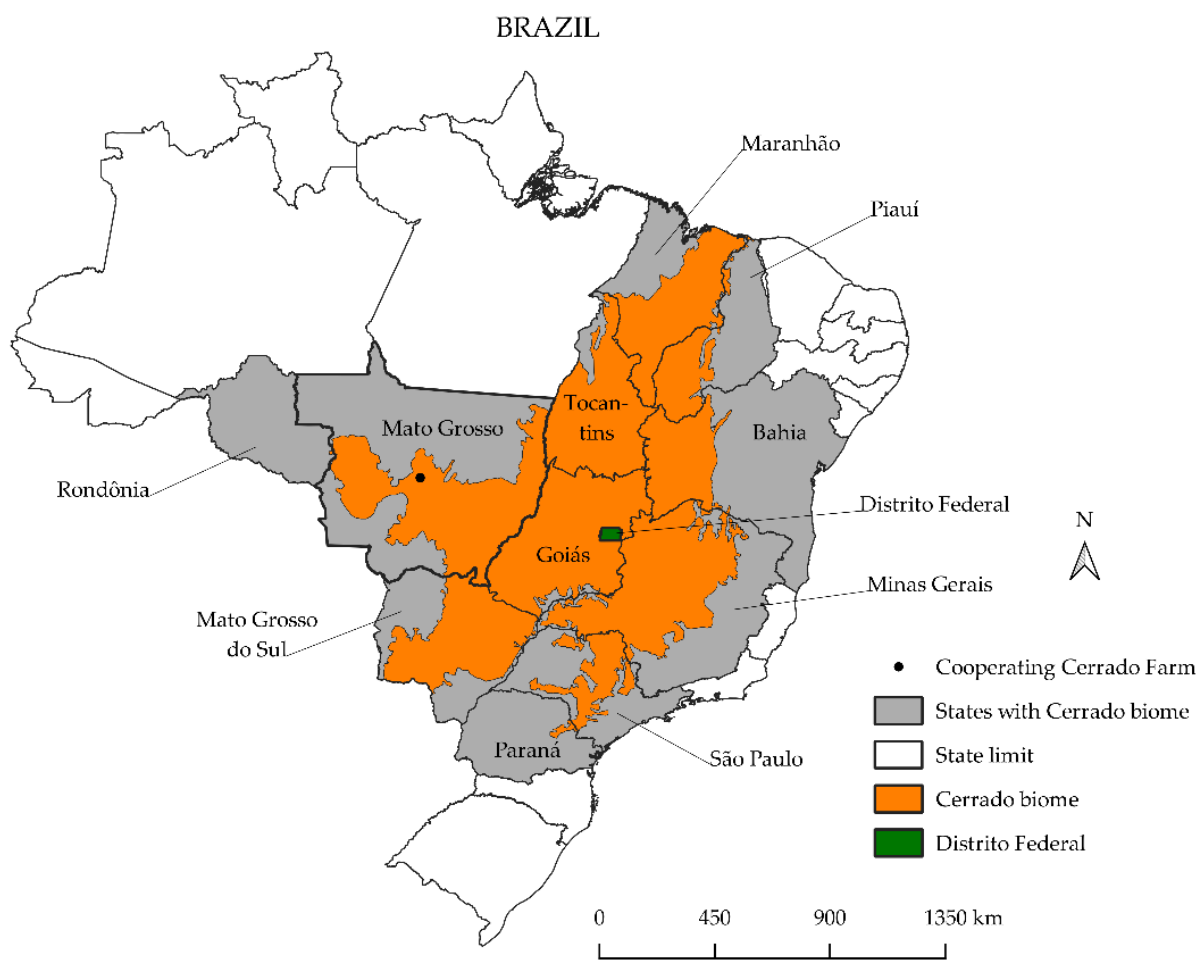

Figure 2. Cooperating farm location for corn silage/grain evaluation in Cerrado biome, Mato Grosso, Brazil.

\subsection{Experimental Design, Soil Testing, and Weather}

Our experiment tested second-crop (safrinha) corn hybrids during the 2020 dry season at Fazenda Bragança (Bragança Agronegócios) farm, in the municipality of Lucas do Rio Verde, Mato Grosso, Brazil (Figure 2) following 2019-2020 wet-season soybeans. The region has a tropical savannah with dry winter (Aw) Köppen climate classification. The experiment used a randomized block design with three blocks, 20 treatments, and 3 replications. Each treatment corresponded to a particular corn hybrid. Each plot was composed of fifteen 25-meter $(\mathrm{m})$ rows, with a dimension of $7.5 \mathrm{~m} \times 25 \mathrm{~m}=187.5 \mathrm{~m}^{2} /$ plot. The area of the contiguous experimental area on-farm was 3 blocks $\times 20$ treatments $=60$ plots $\times 187.5 \mathrm{~m}^{2} /$ plot $=11,250 \mathrm{~m}^{2}=1.125$ hectares (ha). The experiment used a spacing of $0.50 \mathrm{~m}$ between rows and three plants per meter, corresponding to a density of approximately 60,000 plants/ha. The 20 corn hybrids were obtained from different 
seed-producing companies that differed in terms of color, texture, maturation, use, and production technology (Table 1).

Table 1. Characteristics of corn hybrids evaluated for ensiled forage and grain production ${ }^{\text {a }}$.

\begin{tabular}{|c|c|c|c|c|c|}
\hline Hybrid & Grain Color & Grain Texture & Cycle b & Fitness & Technology \\
\hline K9555 VIP3 & Orange & Semi-hard & M & Double & Agrisure Viptera 2 \\
\hline K 9606 VIP3 & Orange & Semi-hard & $\mathrm{E}$ & Double & Agrisure Viptera 3 \\
\hline LG 36790 PRO3 & Orange & Hard & E & Grain & VT PRO3 \\
\hline LG 3040 VIP3 & Orange & Semi-hard & E & Double & Agrisure Viptera 3 \\
\hline MG 652 PWU & Yellow-Orange & Semi-hard & $\mathrm{E}$ & Double & PowerCore Ultra \\
\hline MG 600 PW & Yellow-Orange & Semi-hard & E & Grains & PowerCore \\
\hline AG 8065 PRO3 & $\mathrm{N} / \mathrm{A}$ & $\mathrm{N} / \mathrm{A}$ & $\mathrm{E}$ & $\mathrm{N} / \mathrm{A}$ & VT PRO3 \\
\hline AG 8088 PRO2 & Orange & Hard & E & Grain & VT PRO2 \\
\hline AS 1820 PRO3 & Yellow-Orange & Dented & $\mathrm{E}$ & Grain & VT PRO3 \\
\hline AS 1822 PRO3 & $\mathrm{N} / \mathrm{A}$ & $\mathrm{N} / \mathrm{A}$ & $\mathrm{N} / \mathrm{A}$ & Grain & VT PRO3 \\
\hline BM 790 PRO2 & Orange & Dented & E & Double & VT PRO2 \\
\hline BM 709 PRO2 & Yellow & Semi-dented & $\mathrm{E}$ & Double & VT PRO2 \\
\hline SHS 7930 PRO2 & Yellow & Semi-dented & E & Double & VT PRO2 \\
\hline SHS 7990 PRO3 & Yellow & Semi-dented & E & Double & VT PRO3 \\
\hline 20A44 VIP3 & Yellow-Orange & Semi-hard & E & Double & Agrisure Viptera 3 \\
\hline 20A07 TP2 & Yellow-Orange & Semi-hard & $\mathrm{E}$ & Double & VT PRO2 \\
\hline SZD 106 VIP3 & $\mathrm{N} / \mathrm{A}$ & $\mathrm{N} / \mathrm{A}$ & $\mathrm{N} / \mathrm{A}$ & $\mathrm{N} / \mathrm{A}$ & Agrisure Viptera 3 \\
\hline 9801-20 VIP3 & Orange & $\mathrm{N} / \mathrm{A}$ & $\mathrm{E}$ & Grain & Agrisure Viptera 3 \\
\hline SYN 455 VIP3 & Yellow-Orange & Semi-hard & SE & Grain & Agrisure Viptera 3 \\
\hline SYN 522 VIP3 & Orange & Semi-hard & $\mathrm{P}$ & Grain & Agrisure Viptera 3 \\
\hline
\end{tabular}

${ }^{a}$ Some category characteristics were N/A = Not Available. ${ }^{b}$ Season growth cycle specified as E = Early; SE = Super early; $\mathrm{M}=$ Medium.

The soil at the experimental site is classified as a Latosol. Soil was sampled from 15 random locations in the experimental area at a depth of 0 to $20 \mathrm{~cm}$. These 15 samples were then mixed and sent in for comprehensive soil analyses of macronutirent and micronutrient content as well as cation exchange capacities to Laboratorio Solos and Plantas-Agroanálises at Avenida Brazil, 571- Centro-CEP 78890-000 in Sorriso, Mato Grosso, Brazil. Macronutrient and micronutrient contents were measured in milligrams $(\mathrm{mg})$ per cubic decimeter $\left(\mathrm{dm}^{3}\right)$ where $1 \mathrm{dm}^{3}=1 \mathrm{~L}$ of volume. Cation exchanges capacities were measured as centimoles of charge $\left(\mathrm{cmol}_{\mathrm{c}}\right)$ per $\mathrm{dm}^{3}$. Percentage of organic matter of the soil sample was also tested along with base saturation percentage. Soil had water $\mathrm{pH}$ of 6.1. Macronutrient content for phosphorus $(\mathrm{P})$ was 9.90 milligrams $(\mathrm{mg})$ per cubic decimeter $\left(\mathrm{dm}^{3}\right)$, while for potassium $\left(\mathrm{K}^{+}\right)$this was $64.80 \mathrm{mg} / \mathrm{dm}^{3}$. Micronutrient content of sulfur $(\mathrm{S})$ was $3.70 \mathrm{mg} / \mathrm{dm}^{3}$. Cation exchanges capacities for the soil sample were 2.12 centimoles of charge $\left(\mathrm{cmol}_{\mathrm{c}}\right)$ per $\mathrm{dm}^{3}$ for $\mathrm{Ca}^{+2}, 0.74 \mathrm{cmol}_{\mathrm{c}} / \mathrm{dm}^{3}$ for $\mathrm{Mg}^{+2}$, and $0.00 \mathrm{cmol}_{\mathrm{c}} / \mathrm{dm}^{3}$ for $\mathrm{Al}^{+3}$. Soil organic matter (OM) was $2.4 \%$. Base saturation (V) was $60.60 \%$.

Daily precipitation in millimeters $(\mathrm{mm})$ from February to May 2020 from a rain gauge station located $\sim 42 \mathrm{~km}$ away from our cooperating farm was obtained from Agência Nacional de Água (ANA) [31] in order to determine if there was adequate rainfall during critical crop growth stages (e.g., germination, anthesis, and grain fill). Nearby precipitation during germination ( $92.9 \mathrm{~mm}$ from $25-28$ February 2020), anthesis (i.e., pollination, $44.8 \mathrm{~mm}$ from 12-18 April 2020), and grain fill ( $80.5 \mathrm{~mm}$ from 1-15 May 2020) were adequate with total precipitation of $516.1 \mathrm{~mm}$ from plant until grain sampling during the harvest window (Figure 3 ). 


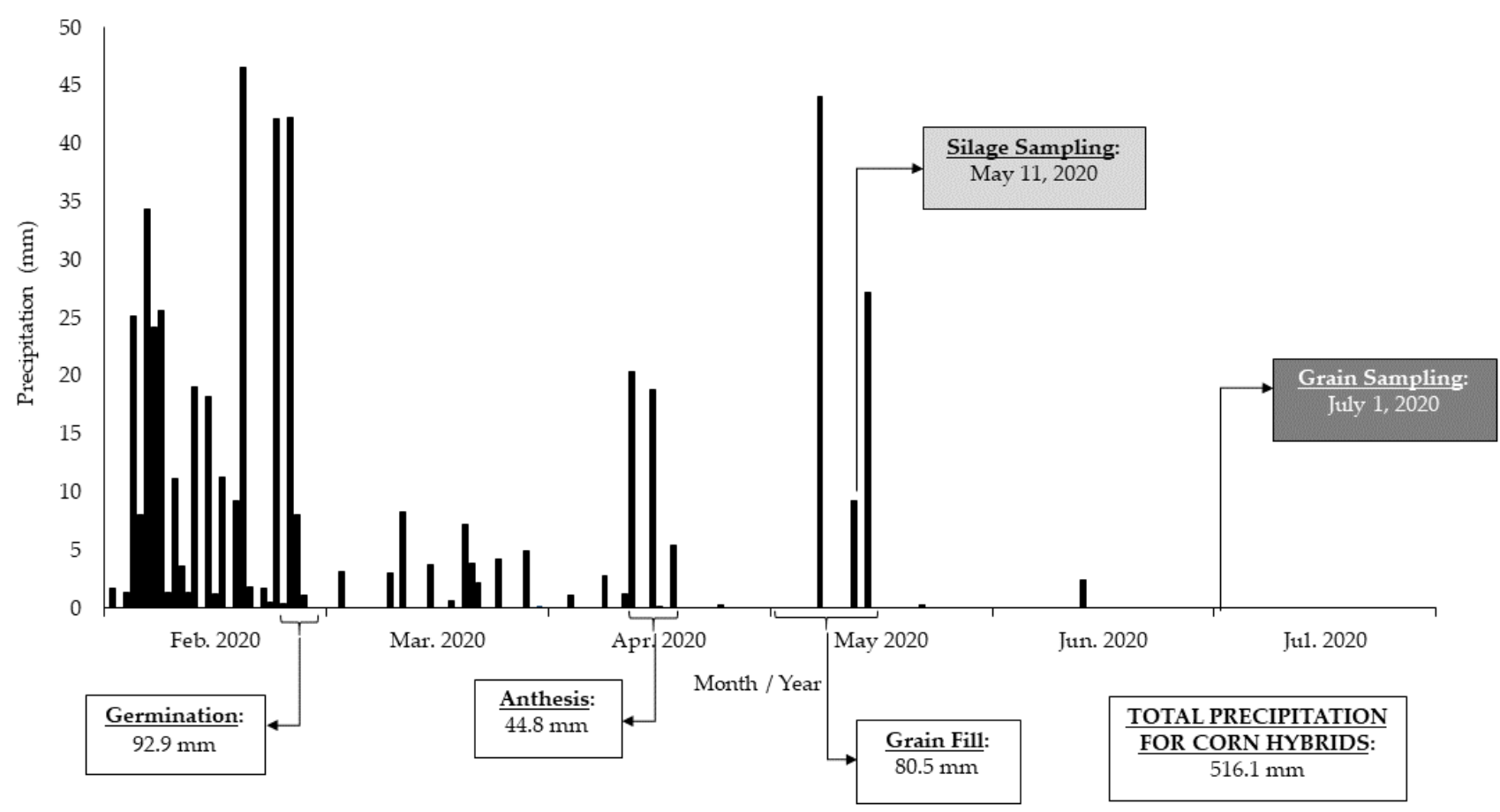

Figure 3. Daily precipitation (mm) and precipitation accumulation for critical corn hybrid growth periods.

Accumulated precipitation for Brazil from February to May 2020 indicates that most regions had at least $400 \mathrm{~mm}$ (light to darker blue areas) over this four month safrinha season with the exception of southern, southwestern, and northeastern Brazil (Figure 1). Precipitation for germination appeared adequate throughout Brazil's Cerrado during February 2020 (Figure A1, Appendix A). March 2020 was in general drier compared to February 2020 as the dry season approached (Figure A2, Appendix A). Rainfall was $<30 \mathrm{~mm}$ for the whole month of April (Figure A3, Appendix A) during anthesis (i.e., pollination) in Mato Grosso's western Cerrado in the heart of the state's soybean industry. Northern Mato Grosso, central Goiás, and eastern Matopiba received $<20 \mathrm{~mm}$ for the entire month of May during grain fill (Figure A4, Appendix A).

Since the nearby rain gauge station only measured precipitation, we also summarized temperature, relative humidity, and wind speed data from a weather station in São José do Rio Claro located $61.4 \mathrm{~km}$ away from our cooperating farm with data from 2003 to 2021 from Instituto Nacional de Meteorologia (INMET) [32]. Precipitation in 2020 was higher than the 2003 to 2021 average and outside the upper 95\% confidence interval (CI) for February and May, while being lower and below the lower 95\% CI in March. Maximum temperature was higher from February to April compared to this historical average, while minimum temperature was higher in February and lower in April and May. Relative humidity was relatively lower during March to May 2020 (Table 2).

Table 2. Weather data from nearby rain gauge $(\sim 42 \mathrm{~km})$ and weather station $(61.4 \mathrm{~km})$ to cooperating farm.

\begin{tabular}{|c|c|c|c|c|c|}
\hline \multirow{2}{*}{$\begin{array}{l}\text { Monthly Average or } \\
\text { 95\% CI/Year(s) }{ }^{a}\end{array}$} & \multirow{2}{*}{$\begin{array}{l}\text { Precipitation } \\
(\mathrm{mm})\end{array}$} & \multicolumn{2}{|c|}{ Temperature $\left({ }^{\circ} \mathrm{C}\right)$} & \multirow{2}{*}{$\begin{array}{l}\text { Relative Humidity } \\
\text { (\% of Saturation) }\end{array}$} & \multirow{2}{*}{$\begin{array}{l}\text { Wind Speed } \\
\qquad(\mathrm{m} / \mathrm{s})\end{array}$} \\
\hline & & Minimum & Maximum & & \\
\hline \multicolumn{6}{|l|}{ February } \\
\hline 2020 Sum/Avg. ${ }^{c}$ & 341.40 & 22.36 & 32.41 & 83.77 & $\mathrm{~N} / \mathrm{A}$ \\
\hline 2003-2021 Avg. d & 201.75 & 22.10 & 31.10 & 83.74 & 1.34 \\
\hline $95 \%$ CI Lower & 114.63 & 21.96 & 30.87 & 83.17 & 1.29 \\
\hline 95\% CI Upper & 288.87 & 22.24 & 31.33 & 84.31 & 1.39 \\
\hline
\end{tabular}


Table 2. Cont.

\begin{tabular}{|c|c|c|c|c|c|}
\hline \multirow{2}{*}{$\begin{array}{l}\text { Monthly Average or } \\
\text { 95\% CI/Year(s) }{ }^{a}\end{array}$} & \multirow{2}{*}{$\begin{array}{l}\text { Precipitation } \\
(\mathrm{mm})\end{array}$} & \multicolumn{2}{|c|}{ Temperature $\left({ }^{\circ} \mathrm{C}\right)$} & \multirow{2}{*}{$\begin{array}{l}\text { Relative Humidity } \\
\text { (\% of Saturation) }\end{array}$} & \multirow{2}{*}{$\begin{array}{l}\text { Wind Speed } \\
\qquad(\mathrm{m} / \mathrm{s})\end{array}$} \\
\hline & & Minimum & Maximum & & \\
\hline \multicolumn{6}{|l|}{ March } \\
\hline 2020 Sum/Avg. ${ }^{c}$ & 41.30 & 22.18 & 32.95 & 81.67 & $\mathrm{~N} / \mathrm{A}$ \\
\hline 2003-2021 Avg. d & 153.43 & 22.21 & 31.34 & 83.11 & 1.22 \\
\hline 95\% CI Lower & 88.41 & 22.06 & 31.16 & 82.55 & 1.17 \\
\hline 95\% CI Upper & 218.45 & 22.35 & 31.52 & 83.67 & 1.27 \\
\hline \multicolumn{6}{|l|}{ April } \\
\hline 2020 Sum/Avg. ${ }^{c}$ & 50.20 & 20.99 & 33.50 & 80.29 & $\mathrm{~N} / \mathrm{A}$ \\
\hline 2003-2021 Avg. d & 84.36 & 21.37 & 31.74 & 81.34 & 1.10 \\
\hline 95\% CI Lower & 45.53 & 21.19 & 31.55 & 80.74 & 1.06 \\
\hline 95\% CI Upper & 123.19 & 21.56 & 31.94 & 81.93 & 1.14 \\
\hline \multicolumn{6}{|l|}{ May } \\
\hline 2020 Sum/Avg. ${ }^{c}$ & 80.80 & 17.14 & 31.26 & 77.61 & $\mathrm{~N} / \mathrm{A}$ \\
\hline 2003-2021 Avg. ${ }^{d}$ & 19.77 & 18.92 & 31.28 & 78.25 & 1.08 \\
\hline 95\% CI Lower & 6.45 & 18.71 & 31.06 & 77.67 & 1.04 \\
\hline 95\% CI Upper & 33.09 & 19.14 & 31.51 & 78.83 & 1.13 \\
\hline
\end{tabular}

${ }^{\text {a }}$ The $95 \%$ confidence interval (CI) calculated for available monthly data from 2003 to $2021 .{ }^{b}$ Precipitation in 2020 only collected at rain gauge station but not at São José do Rio Claro weather station. ${ }^{c}$ Precipitation is summed over the month, while other weather variables are averaged. ${ }^{\mathrm{d}}$ Average calculated for precipitation and wind speed for data available from 2003 to 2018.

\subsection{Crop Management}

On 20 February 2020, $350 \mathrm{~kg}$ /hectare (ha) of 22-04-12 nitrogen-phosphorus-potassium (NPK) formulation was applied in the sowing row for fertilization while planting corn based on soil tests. Top-dress fertilizer was applied on 9 March 2020, 18 days after planting. Top-dressing used the same amount applied for fertilization before planting. Pest and weed management materials applications were made while corn was in vegetative stages V3 and V4, about 10 days after (19 March 2020) top-dressing fertilization. This included foliar fertilization for micro-nutrients with Sovereign ${ }^{\circledR}(0.2 \mathrm{~L} / \mathrm{ha})$ and application of the broad spectrum herbicide, Roundup ${ }^{\circledR}$ WG $(2.0 \mathrm{~kg} / \mathrm{ha})$, and Primóleo ${ }^{\circledR}(5.0 \mathrm{~L} / \mathrm{ha})$, an herbicide recommended for control of annual weeds in corn. Insecticides applied included two applications of $\operatorname{Hero}^{\circledR}(0.2 \mathrm{~L} / \mathrm{ha})$ and one application of Exalt ${ }^{\circledR}(0.1 \mathrm{~L} / \mathrm{ha})$.

\subsection{Silage Harvest and Bromatological Analysis}

On 11 May 2020, corn hybrid silage production was measured for both green matter and dry matter yields per hectare. Silage was sampled at the harvest point of $\frac{3}{4}$ milk line in the grain and at 30-35\% dry matter in the forage. In each experimental plot, five points were randomly selected and then three meters were measured in the direction of the planting row. At each point, plants on both sides of the 3-meter $(\mathrm{m})$ row were cut at a height of $0.2 \mathrm{~m}=20 \mathrm{~cm}$ from the ground. After cutting, weighing, and identifying all five points, those with greater and lesser weight were removed. The plants from the remaining three points were grouped and taken for processing.

The plants from each plot were fractioned using a stationary forage shredder. The crushed forage was mixed and separated into four parts. Then, two opposite parts were eliminated until obtaining a $0.5 \mathrm{~kg}$ sample of the crushed material. This sample was wrapped in plastic film, compressed, and molded into a sphere. The sample was perforated to remove the air and again wrapped in plastic film, using three layers. Each sample was identified and sent for laboratory bromatological analysis at EsalqLab on 12 May 2020. EsalqLab belongs to the Department of Animal Science of the Higher School of Agriculture "Luiz de Queiroz," Av. Pádua Dias, 11, CEP 13.418-900, Piracicaba campus in the state of São Paulo, Brazil. Dry matter, crude protein, neutral detergent fiber, acid detergent fiber, ether extract, lignin, and in vitro digestibility were determined after $48 \mathrm{~h}$. 


\subsection{Grain Harvest and Bromatological Analysis}

Corn grain was harvested for evaluation on 1 July 2020. Five random points were used within the research plot. At each point, a distance of five meters was measured in the direction of the planting row and all the ears were collected on both sides of the marked distance. After threshing, plot weight and grain yield were determined. A grain sample from each plot was taken to determine crude protein, ether extract, and carbohydrate contents, using the technique of near-infrared spectrophotometry (NIRS). All grain quality analyses including NIRS were conducted at Núcleo de Tecnologia em Armazenagem (NTA) at FAAZ, Universidade Federal de Mato Grosso, Cuiabá, Mato Grosso (MT) state, Brazil. After grain sampling and conclusion of the corn crop, the typical phytosanitary break was taken until October 2020 when the experimental area was planted with soybeans as is typical in MT or Brachiaria spp. to establish a no-till experimental system.

\subsection{Statistical Analysis}

All corn silage and grain yield and quality data were analyzed using analysis of variance (ANOVA). After the normal distribution of errors was confirmed by the ShapiroWilk test, the means were compared with the Scott-Knott test at $5 \%$ probability. Pearson's correlation ( $\mathrm{r}$ ) was calculated for collected data. In addition, a multivariate principal component analysis (PCA) was performed for all crop characteristics. PCA is an analysis aimed at reducing the dimensionality of a group of correlated variables. This process takes place by creating a new group of uncorrelated variables that are ordered in ascending order according to the portion of variation present in the total variation of the original variables [33]. During PCA analysis, an " $n \times p$ " matrix is determined, where $n$ corresponds to the number of treatments $(n=20)$ and " $p$ " to the number of analyzed variables $(p=13)$. Eigenvalues and eigenvectors were calculated based on the covariance matrices and plotted in two-dimensional graphics (biplot: category ordering diagram and correlation circle) generated from the Factoextra package [34]. The R statistical software was used for summary statistical, ANOVA, and PCA analyses (R CORE TEAM, 2020).

\section{Results}

\subsection{Silage Yields and Quality}

The variables green matter yield (GMY) and dry matter yield (DMY), as well as dry matter (DMf) content of forage (f) as silage, did not differ among corn hybrids $(p>0.05)$. The mean values for these variables were 42.85 metric tons/hectare, 13.59 metric tons/hectare, and 31.92\%, respectively (Table 3). Except for hybrids 20A07 TP2, LG 3040 VIP3, and MG 600 PW, all others showed, in absolute values, dry matter contents ranging between 30 and $35 \%$, which is considered to be an adequate range for corn silage production [4]. However, these dry matter (DMf) percentages below $30 \%$ were not significant different from the other corn hybrids using the Scott-Knott test $(p<0.05)$. Crude protein (CPf), neutral detergent fiber (NDFf), acid detergent fiber (ADFf), and ether extract (EEf) contents were not significantly different (Table 4) using the Scott-Knott test $(p<0.05)$. However, both lignin (LIGf) content of sampled corn silage as well as in vitro digestibility (IVDf) of forage dry matter for different ensiled corn hybrids were significantly different (Table 4).

Table 3. Green matter yield (GMY), dry matter yield (DMY), and dry matter (DMf) percent of ensiled forage (f) for different corn hybrids for Cerrado biome, Mato Grosso, Brazil.

\begin{tabular}{lccr}
\hline Hybrid & $\begin{array}{c}\text { GMY (Metric } \\
\text { tons/Hectare) }\end{array}$ & $\begin{array}{c}\text { DMY (Metric } \\
\text { tons/Hectare) }\end{array}$ & DMf (\%) $^{\mathbf{a}}$ \\
\hline AS 1822 PRO3 & 44.78 & 15.10 & 33.97 \\
SYN 455 VIP3 & 48.25 & 14.94 & 31.23 \\
BM 790 PRO2 & 44.30 & 14.40 & 32.57 \\
K9555 VIP3 & 45.47 & 14.02 & 30.83 \\
\hline
\end{tabular}


Table 3. Cont.

\begin{tabular}{lccc}
\hline \multicolumn{1}{c}{ Hybrid } & $\begin{array}{c}\text { GMY (Metric } \\
\text { tons/Hectare) }\end{array}$ & $\begin{array}{c}\text { DMY (Metric } \\
\text { tons/Hectare) }\end{array}$ & ${ }^{\mathbf{a}}$ \\
\hline AS 1820 PRO3 & 40.75 & 14.01 & 34.47 \\
K 9606 VIP3 & 43.97 & 13.87 & 31.70 \\
MG 600 PW & 46.33 & 13.80 & 29.77 \\
20A44 VIP3 & 43.52 & 13.74 & 31.70 \\
20A07 TP2 & 48.26 & 13.70 & 28.53 \\
9801-20 VIP3 & 40.35 & 13.69 & 33.97 \\
BM 709 PRO2 & 39.32 & 13.67 & 34.67 \\
LG 36790 PRO3 & 41.48 & 13.67 & 33.17 \\
LG 3040 VIP3 & 45.17 & 13.53 & 29.97 \\
SYN 522 VIP3 & 43.36 & 13.49 & 31.17 \\
SHS 7930 PRO2 & 39.94 & 13.15 & 33.40 \\
SZD 106 VIP3 & 43.08 & 13.02 & 30.53 \\
AG 8065 PRO3 & 39.52 & 12.86 & 32.60 \\
SHS 7990 PRO3 & 37.37 & 12.50 & 33.50 \\
MG 652 PWU & 40.55 & 12.33 & 30.63 \\
AG 8088 PRO2 & 41.21 & 12.29 & 30.07 \\
\hline Average & 42.85 & 13.59 & 31.92 \\
\hline CV (\%) ${ }^{\text {b }}$ & 11.28 & 9.84 & 7.36 \\
\hline
\end{tabular}

${ }^{\mathrm{a}}$ Means did not differ from each other by the Scott-Knott test $(p<0.05) \cdot{ }^{\mathrm{b}} \mathrm{CV}=$ coefficient of variation.

Table 4. Forage (f) crude protein (CPf), neutral detergent fiber (NDFf), acid detergent fiber (ADFf), lignin (LIGf), ether extract (EEf), and in vitro digestibility (IVDf) of dry matter for different corn hybrids ensiled as silage.

\begin{tabular}{|c|c|c|c|c|c|c|c|}
\hline Lignin/Digestibility & Hybrid & $\operatorname{CPf}(\%)^{a}$ & NDFf $(\%)^{a}$ & ADFf (\%) ${ }^{a}$ & LIGf (\%) & EEf $(\%)^{a}$ & IVDf $(\%)^{b}$ \\
\hline \multirow[t]{15}{*}{ Low/High } & AS 1822 PRO3 & 8.93 & 45.93 & 27.33 & $2.80 \mathrm{~b}$ & 3.47 & $61.00 \mathrm{a}$ \\
\hline & MG 600 PW & 9.40 & 49.70 & 29.47 & $3.23 \mathrm{~b}$ & 3.37 & $60.00 \mathrm{a}$ \\
\hline & 9801-20 VIP3 & 8.93 & 49.53 & 28.23 & $3.27 b$ & 3.50 & $62.33 \mathrm{a}$ \\
\hline & K9555 VIP3 & 8.67 & 48.50 & 29.77 & $3.30 \mathrm{~b}$ & 3.23 & $61.33 \mathrm{a}$ \\
\hline & AS 1820 PRO3 & 9.53 & 50.13 & 29.57 & $3.37 \mathrm{~b}$ & 3.50 & $60.67 \mathrm{a}$ \\
\hline & AG 8065 PRO3 & 8.83 & 45.07 & 27.10 & $3.37 \mathrm{~b}$ & 3.50 & $61.67 \mathrm{a}$ \\
\hline & MG 652 PWU & 9.40 & 47.77 & 29.27 & $3.40 \mathrm{~b}$ & 3.80 & $61.00 \mathrm{a}$ \\
\hline & Low/High Avg. & 9.23 & 48.97 & 29.35 & 3.40 & 3.27 & 61.21 \\
\hline & SYN 522 VIP3 & 9.33 & 49.23 & 29.40 & $3.43 \mathrm{~b}$ & 3.33 & $63.33 \mathrm{a}$ \\
\hline & LG 36790 PRO3 & 8.83 & 48.93 & 29.77 & $3.50 \mathrm{~b}$ & 3.43 & $62.00 \mathrm{a}$ \\
\hline & SZD 106 VIP3 & 9.53 & 49.00 & 30.27 & $3.50 \mathrm{~b}$ & 3.10 & $60.33 \mathrm{a}$ \\
\hline & SYN 455 VIP3 & 9.63 & 50.20 & 30.23 & $3.53 \mathrm{~b}$ & 2.70 & $60.33 a$ \\
\hline & K 9606 VIP3 & 8.83 & 49.07 & 29.90 & $3.60 \mathrm{~b}$ & 3.03 & $61.67 \mathrm{a}$ \\
\hline & LG 3040 VIP3 & 9.87 & 51.87 & 31.00 & $3.63 \mathrm{~b}$ & 2.80 & $61.00 \mathrm{a}$ \\
\hline & 20A44 VIP3 & 9.47 & 50.63 & 29.63 & $3.70 \mathrm{~b}$ & 3.07 & $60.33 a$ \\
\hline \multirow[t]{5}{*}{ Medium/Mixed } & SHS 7930 PRO2 & 8.30 & 49.97 & 30.33 & $3.90 \mathrm{a}$ & 3.30 & $60.67 \mathrm{a}$ \\
\hline & AG 8088 PRO2 & 9.80 & 53.73 & 32.07 & $3.93 \mathrm{a}$ & 3.47 & $62.00 \mathrm{a}$ \\
\hline & Med./Mix. Avg. & 9.11 & 53.49 & 31.84 & 3.97 & 3.05 & 60.59 \\
\hline & 20A07 TP2 & 9.13 & 56.60 & 33.67 & $4.00 \mathrm{a}$ & 2.90 & $59.67 \mathrm{ab}$ \\
\hline & SHS 7990 PRO3 & 9.20 & 53.67 & 31.30 & $4.03 \mathrm{a}$ & 2.53 & $60.00 \mathrm{a}$ \\
\hline \multirow[t]{5}{*}{ High/Low } & BM 790 PRO2 & 8.53 & 49.73 & 31.10 & $4.17 \mathrm{a}$ & 3.00 & $59.00 \mathrm{~b}$ \\
\hline & High/Low Avg. & 8.28 & 50.95 & 32.19 & 4.42 & 2.70 & 55.84 \\
\hline & BM 709 PRO2 & 8.03 & 52.17 & 33.27 & $4.67 \mathrm{a}$ & 2.40 & $52.67 \mathrm{~b}$ \\
\hline & Average & 9.11 & 50.07 & 30.13 & 3.62 & 3.17 & 60.55 \\
\hline & $\mathrm{CV}(\%)^{\mathrm{c}}$ & 8.70 & 7.19 & 8.07 & 12.10 & 15.85 & 3.97 \\
\hline
\end{tabular}

${ }^{\mathrm{a}}$ Means did not differ from each other by the Scott-Knott test $(p<0.05) .{ }^{\mathrm{b}}$ Means followed by different letters in column differ from each other by the Scott-Knott test $(p<0.05)$. ${ }^{c} \mathrm{CV}=$ coefficient of variation.

Corn plants in the form of ensiled forage ( $\mathrm{f}$ ) are expected to show higher consumption owing to their relatively low neutral detergent fiber (NDFf) content (less than $50 \%$ ), and the lower the NDF content, the higher the fermentation rate and the faster the animals' 
rumen emptying [35]. In this context regarding fiber content, hybrids we evaluated with NDFf under $50 \%$ and dry matter yield (DMY) of $~ 13.5$ metric tons/hectare or more were AS 1822 PRO3, K9555 VIP3, LG 36790 PRO3, K 9606 VIP3, SYN 522 VIP3, 9801-20 VIP3, MG $600 \mathrm{PW}$, and BM 790 PRO2 (Tables 2 and 3). However, if other factors such as production costs are considered, hybrids that do not differ statistically from others in terms of yield and that contain less than $50 \% \mathrm{NDF}$, such as MG $652 \mathrm{PWU}$, could be recommended.

For lignin content, significantly higher values $\geq 3.9 \%$ were found in six hybrids (Table 4). Lignin is a natural phenolic polymer of high molecular weight, with a complex composition and structure. Biosynthesis of this compound extensively stimulates plant growth, tissue/organ development, lodging resistance, and responses to a variety of biotic and abiotic stresses [36,37]. Corn plants can remain upright with less than $5 \%$ lignin, and higher lignin means more indigestible material which reduces forage nutritional value $[7,8]$. For lignin content of forage (LIGf), 14 hybrids had significantly lower values between 2.8 and $3.7 \%$ (Table 4 ) indicating greater potential silage digestibility.

Lower in vitro digestibility of forage (IVDf) dry matter was found for hybrids BM 709 PRO2 and BM 790 PRO2, and both also had higher lignin content (Table 4). It is known that the presence of lignin in cell walls negatively impacts the forage digestibility of various plant species [38]. Forage fiber digestibility is directly influenced by lignin-carbohydrate linkages, which vary according to hybrid and species, as well as by the agronomic conditions when the plant was grown which may affect the variation in fiber content in different grass species [39]. Corn hybrids to avoid were 20A07 TP2 and BM 709 PRO2 with high fiber (NDFf) and lignin (LIGf) values and lower IVDf (Table 4), in addition to low grain yield (Table 5).

Table 5. Crude protein (CPg), ether extract (EEg), soluble carbohydrates (SCg), and grain yield (GY) of corn hybrid corn grain (g) for Cerrado biome, Mato Grosso, Brazil.

\begin{tabular}{|c|c|c|c|c|c|}
\hline Grain Yield (GY) & Hybrid & $\operatorname{CPg}(\%)^{a}$ & $\operatorname{EEg}(\%)^{a}$ & $\operatorname{SCg}(\%)^{a}$ & GY (kg/hectare) ${ }^{b}$ \\
\hline \multirow[t]{11}{*}{ High } & AS 1820 PRO3 & 8.07 & 3.26 & 88.35 & $12,309.16 \mathrm{a}$ \\
\hline & K 9606 VIP3 & 7.99 & 3.45 & 87.95 & $12,200.99 a$ \\
\hline & SYN 455 VIP3 & 8.06 & 3.29 & 87.72 & $11,573.13 \mathrm{a}$ \\
\hline & BM 790 PRO2 & 7.94 & 3.31 & 88.16 & $11,498.58 \mathrm{a}$ \\
\hline & High Average & 8.00 & 3.42 & 88.07 & $11,425.38$ \\
\hline & SYN 522 VIP3 & 8.13 & 3.44 & 88.35 & $11,398.25 \mathrm{a}$ \\
\hline & SZD 106 VIP3 & 7.65 & 3.54 & 87.65 & $11,341.05 \mathrm{a}$ \\
\hline & MG 600 PW & 7.81 & 3.45 & 88.55 & $11,247.72 \mathrm{a}$ \\
\hline & MG 652 PWU & 8.11 & 3.37 & 88.17 & $10,964.59 \mathrm{a}$ \\
\hline & LG 36790 PRO3 & 7.99 & 3.73 & 88.04 & $10,881.82 \mathrm{a}$ \\
\hline & 9801-20 VIP3 & 8.29 & 3.36 & 87.74 & $10,838.50 \mathrm{a}$ \\
\hline \multirow[t]{9}{*}{ Medium } & K 9555 VIP3 & 7.84 & 3.70 & 88.45 & $10,407.24 \mathrm{~b}$ \\
\hline & AG 8065 PRO3 & 7.83 & 3.52 & 88.16 & $10,382.67 \mathrm{~b}$ \\
\hline & AS 1822 PRO3 & 7.80 & 3.40 & 88.40 & $10,182.79 \mathrm{~b}$ \\
\hline & LG 3040 VIP3 & 8.13 & 3.27 & 88.37 & $10,135.03 \mathrm{~b}$ \\
\hline & Medium Average & 8.00 & 3.57 & 88.15 & 9962.68 \\
\hline & 20A44 VIP3 & 7.92 & 3.70 & 88.11 & $9926.02 \mathrm{~b}$ \\
\hline & 20A07 TP2 & 8.30 & 3.70 & 87.68 & $9619.48 \mathrm{~b}$ \\
\hline & AG 8088 PRO2 & 8.20 & 3.42 & 88.22 & $9548.52 \mathrm{~b}$ \\
\hline & SHS 7930 PRO2 & 8.00 & 3.81 & 87.83 & $9499.65 \mathrm{~b}$ \\
\hline Low & BM 709 PRO2 & 8.17 & 3.49 & 87.52 & $8207.70 \mathrm{c}$ \\
\hline \multirow[t]{3}{*}{ Very Low } & SHS 7990 PRO3 & 8.06 & 3.39 & 87.80 & $6974.17 \mathrm{~d}$ \\
\hline & Average & 8.02 & 3.48 & 88.06 & $10,456.85$ \\
\hline & $\mathrm{CV}(\%)^{\mathrm{c}}$ & 3.01 & 10.15 & 0.51 & 8.02 \\
\hline
\end{tabular}

${ }^{a}$ Means did not differ from each other by the Scott-Knott test $(p<0.05) .{ }^{b}$ Means followed by different letters in yield column differ from each other by the Scott-Knott test $(p<0.05) .{ }^{\mathrm{c}} \mathrm{CV}=$ coefficient of variation. 


\subsection{Grain Yields and Quality}

Bromatological results and grain (g) yield of the 20 corn hybrids indicated no significant difference $(p>0.05)$ for the variables crude protein $(\mathrm{CPg})$, ether extract $(\mathrm{EEg})$, and soluble carbohydrate $(\mathrm{SCg})$. Grain yield $(\mathrm{GY}=\mathrm{kg} /$ hectare) differed significantly among the hybrids, with statistically significant differences in groupings for high $(10,838.50$ to 12,309.16) and medium (9499.65 to 10,407.24) as well as one hybrid (BM 709 PRO2) with low yield (8207.70) and another hybrid (SHS 7990 PRO3) with very low (6974.17) yield (Table 5). Pearson's correlation analysis (Figure 4) showed positive and significant correlations between grain yield (GY) and fiber (NDFf) and lignin (LIGf) contents for forage. Soluble carbohydrates of grain (SCg) were negatively and significantly correlated with both fiber (NDFf) and lignin (LIGf) contents of forage. SCg was positively and significantly correlated with ether extract of forage (EEf). There was a negative correlation $(-0.69)$ between LIGf and in vitro digestibility (IVDf) of forage dry matter, which is consistent with silage lignin values that are statistically significantly lower associated with higher silage in vitro digestibility and vice versa (Table 4 ).

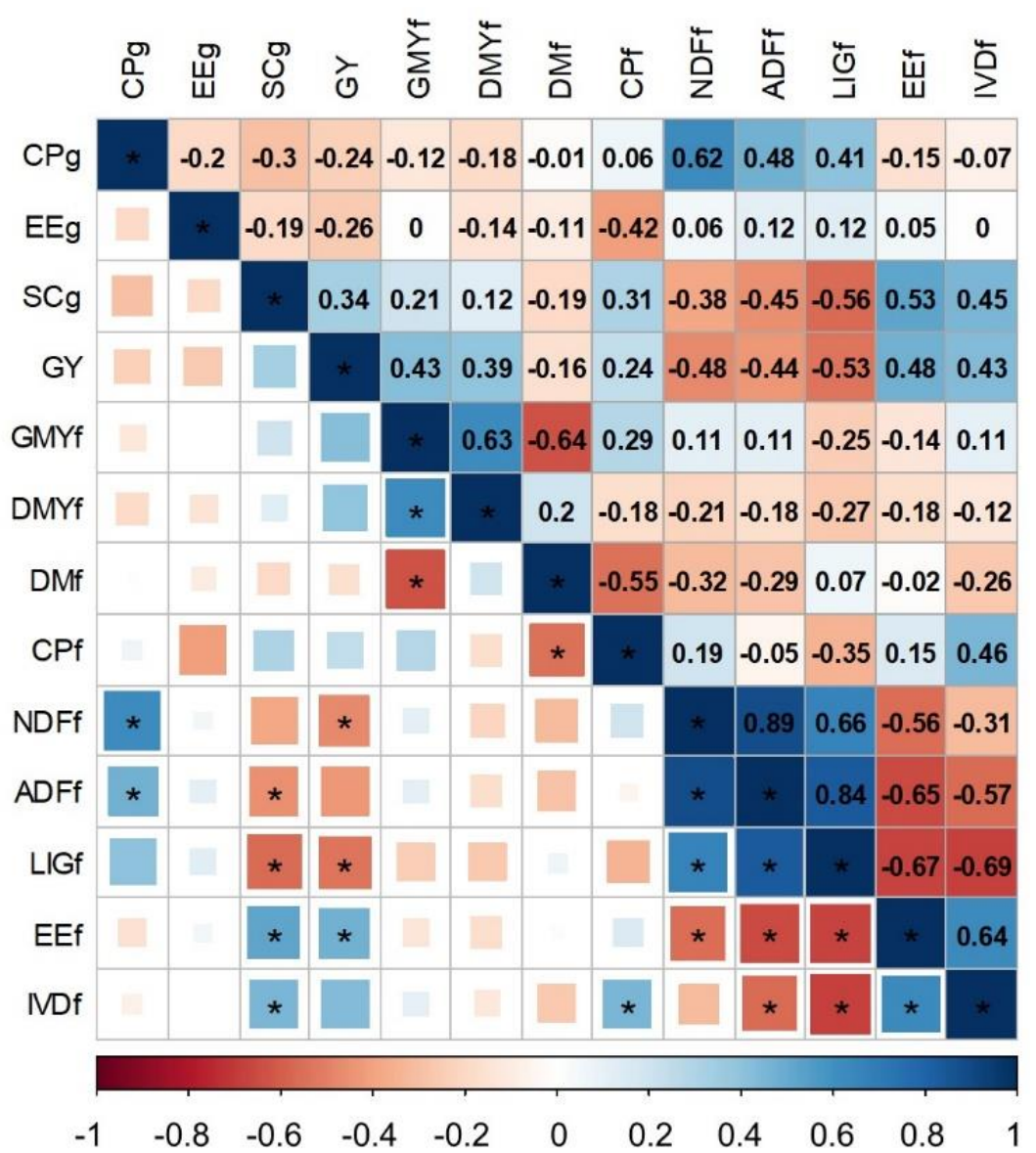

Figure 4. Pearson's correlation (r) (B) determined by the linear combination of grain and forage variables of 20 corn hybrids. *: Significant correlation at $5 \%$ probability by the $t$-test.

\subsection{Principal Components Analysis}

Principal component analysis (PCA) showed that the sum of components 1 (PC1) and 2 (PC2) accounted for $55.2 \%$ of the total variability of the data (Figure 5). In this context, 12 hybrids were concentrated in the positive scores of PC1, close to the variables GMYf, CPf, IVDf, DMYf, GY, SCg, and EEf. These results reinforce a greater potential for using these hybrids in the study region. Although they were not significantly superior in these variables, in general they clearly showed a trend towards the greater potential for both silage and grain production. On the other hand, eight hybrids were close to vectors NDFf, 
ADFf, CPg, EEg, LIGf and DMf, reinforcing the greater tendency for these hybrids to produce lower quality silage. This trend is mainly explained by the opposite concentration of these vectors for in vitro digestibility of forage (IVDf). In this sense, one can negatively highlight hybrids 20A07TP2, BM 709 PRO2, and SHS7990 PRO3, which clearly showed a greater distance from these vectors that are related to silage and grain quality. These results reinforce the low potential for use. In general, they had higher lignin contents combined with lower digestibility, in addition to lower grain yield (Tables 3-5).

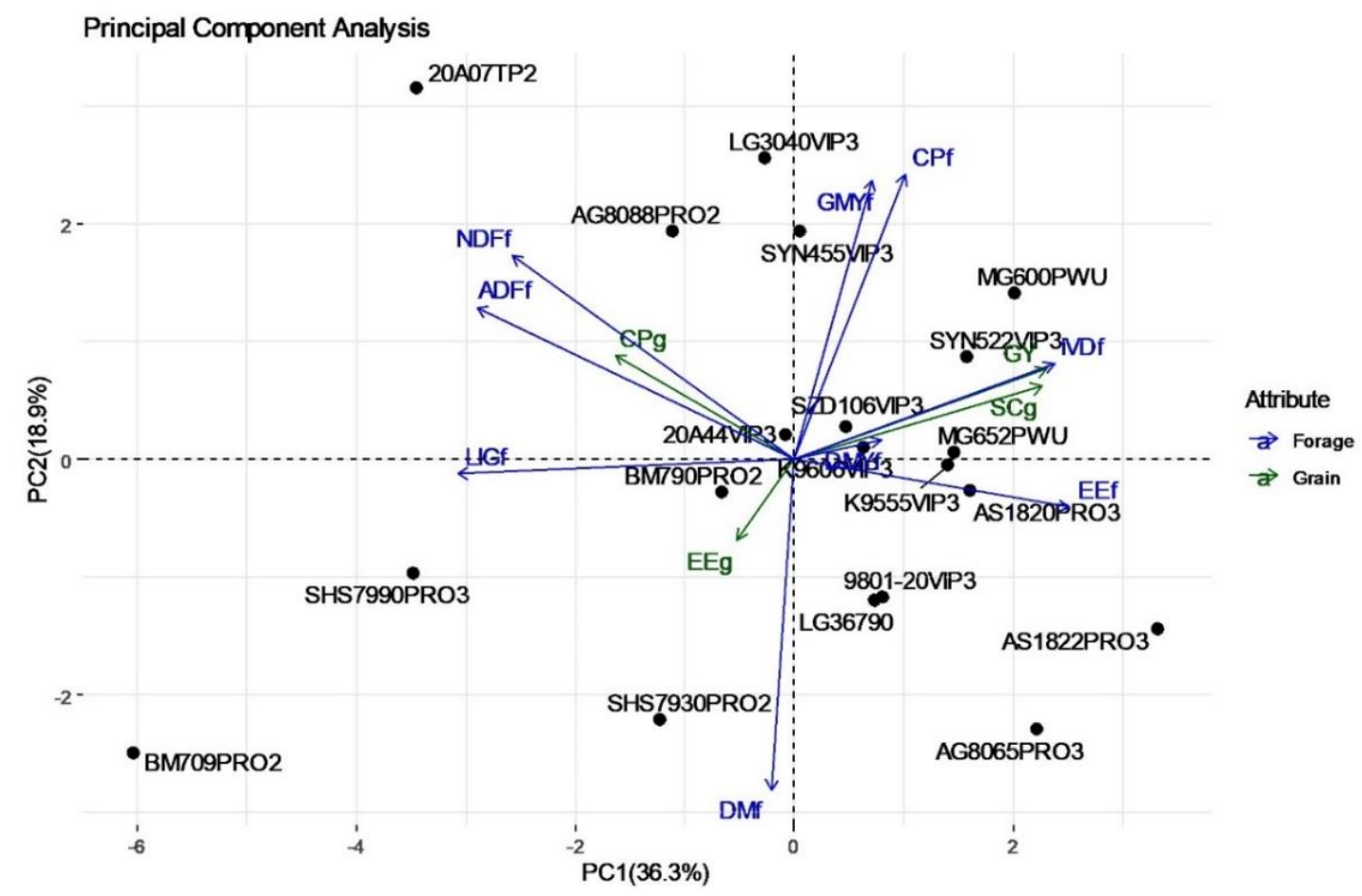

Figure 5. Biplot resulting from principal component analysis (PCA), determined by the linear combination of grain and forage variables of 20 corn hybrids. PC1: Principal component 1; PC2: Principal component 2.

\section{Discussion}

\subsection{Comparison to Previous Studies}

Our results are consistent with a study of 18 corn hybrids during the 2003-2004 wet-season in southern Minas Gerais state in southeastern Brazil, which concluded that choosing hybrids with high digestibility is essential for the production of quality corn silage [40]. Unlike our results, evaluation of 19 corn hybrids for silage in Rio de Janeiro state in southeastern Brazil during the 2013 and 2014 dry seasons found that green matter yield can be used for indirect selection of bromatological quality [41]. Our 2020 dry-season average green matter yield (GMY) for corn silage (42.85 metric tons (t)/hectare (ha); Table 3) was $34.9 \%$ greater than average corn silage GMY $(31.78 \mathrm{t} / \mathrm{ha})$ in this same southeastern Brazil study, with our GMY having 25.8\% lower standard deviation [41]. The average corn silage dry matter yield (DMY) from our study of $13.59 \mathrm{DM} \mathrm{t} / \mathrm{ha}$ (Table 3) was $9.6 \%$ greater than 12.4 DM t/ha from a study in Minas Gerais for dry-season corn planted January 2003, but not for wet-season corn planted in December $(-13.4 \%)$ and November $(-32.1 \%)$ of 2002 [42]. Corn silage yields from our experiment during the dry season were 6.9 to $62.9 \%$ lower than other wet-season corn silage yields reported in six Brazilian studies (2002-2017) in Mato Grosso so Sul [43], São Paulo [44,45], and Parana [5,46] states. Our average dryseason corn silage DMY was potentially greater (26.3\%) than wet-season average yield (10.76 DM t/ha) in Minas Gerais in 2003, where this study's 5.84 to $15.68 \mathrm{DM} \mathrm{t/ha} \mathrm{range} \mathrm{[47]}$ encompassed our range of 12.29 to $15.1 \mathrm{DM} \mathrm{t} / \mathrm{ha}$ (Table 3). 
Compared to other studies in Brazil, our corn silage forage (f) quality in general had higher crude protein (CPf) but lower digestibility due to higher fiber and lignin contents. For example, compared to the same 2-year study in Mato Grosso do Sul [43] mentioned above, our results were $49.3 \%$ higher for CPf, $1.56 \%$ more for neutral detergent fiber (NDFf), $24.5 \%$ higher for acid detergent fiber (ADFf), and had $16.7 \%$ more lignin (LIGf). Compared to a field experiment evaluating 23 corn hybrids in southern Mato Grosso, Brazil, during the 2009 dry season [48], our corn silage had $12.5 \%$ higher CPf, 15.2\% more NDFf, and $28.9 \%$ greater ADFf, but $14.3 \%$ lower in vitro digestibility of forage (IVDf) dry matter. Compared to previously mentioned studies, our corn silage crude protein was $7.2 \%$ [5], 13.1\% [42], and $21.5 \%$ [46] higher. Meanwhile, our fiber content was $29.1 \%$ and $48.1 \%$ higher for NDFf and $36.4 \%$ and $69.3 \%$ more for ADFf [42,46], while having $16.7 \%$ more LIGf [38]. However, the $6.5 \%$ average value for lignin from the 2002-2003 study in Minas Gerais (MG) state mentioned earlier with a wide range of plant dates and DMY [42] was 79.7\% higher than our average LIGf $=3.62 \%$. This may be due to drought stress, which can increase lignin [49], as this MG 2002-2003 dry-season corn treatment was evaluated when Southeast Brazil was in the middle of a decade long dry period [50].

Past research on corn hybrids in Brazil has focused on measuring grain yield (GY) per hectare (ha) and not quality. The corn grain yields from our present study for secondcrop (safrinha) dry-season corn (Table 5) were comparable to past experimental yields for most first-crop (safra) wet-season corn. This is likely to be due to favorable weather and above average (e.g., May) and/or well-timed rainfall during critical growth stages (Table 2; Figure 3). Our GY was only 5.4 and 6.5\% lower than GY measured in two studies in Paraná state in southeastern Brazil during the 2002-2003 [51] and 2015-2016 [9] wet seasons, respectively. Compared to another Parana experiment testing different row spacings, our corn GY was $16.8 \%$ higher [52]. However, our average corn GY was $25.7 \%$ lower than the $14,070 \mathrm{~kg} /$ ha average reported from an experiment in Goiás during the 2015 dry season and 2015-16 wet season [53]. Dry-season safrinha corn grain yields tend to be lower than for wet-season safra corn, especially in drier areas of the Cerrado [13].

Our average corn GY (10,457 kg/ha; Table 5) was 10.1 to $51.5 \%$ higher compared to past field experiments also conducted during the dry season in Minas Gerais [54], southwestern Goiás and eastern Rondônia [55], and Mato Grosso do Sul (MS) [56] states. Our average corn GY was $252 \%$ more than those for a 2006 dry-season study, averaged across three municipalities in MS at only $2967 \mathrm{~kg} / \mathrm{ha}$ [57]. Compared to past experiments in Mato Grosso (MT) state, our GY for corn hybrids were 24.4 to $68.7 \%$ higher compared to experimental results from studies at the Brazilian Agricultural Research Corporation (Embrapa) Agrossilvipastoril research unit in Sinop, MT [55,58,59], which is $150 \mathrm{~km}$ north of our cooperating farm. The recent statewide 2020 average safrinha corn GY for MT, Brazil, was $6392 \mathrm{~kg} /$ hectare [13], 38.9\% lower than the average corn GY for the hybrids we evaluated.

In our study, corn ears were hand-picked so there was no yield loss. Farmers can experience yield loss from crop lodging in addition to grain loss during harvest with combines. However, corn grain harvest losses in Brazil measured in a 2009 study at the Universidade Federal Viçosa in central Minas Gerais, Brazil, ranged from only 7.3 to $8.2 \%$ for traditional $0.45 \mathrm{~m}$ between row spacing and a wider row spacing of $0.9 \mathrm{~m}$, respectively [60]. This is well below the 55.9 to $78.7 \%$ higher yield of our medium and high yielding groups compared to the 2020 average safrinha corn GY for Mato Grosso, Brazil. Our experimental study's total precipitation (516.1 mm; Figure 3) exceeded that recommended throughout the growing season for corn in the Cerrado of at least 400-500 mm [61-63]. In addition, daily rain events preceded and occurred during germination, anthesis (i.e., pollination), and grain fill (Figure 3), so dry periods during these critical crop growth stages were not evident.

Lack of drought stress unique to the time (February to May 2020) and place where we conducted our on-farm corn hybrid trials may also explain why our experimental GY is likely to be more representative of maximum safrinha corn yield goals rather than 
future expected long-run averages. Corn is sensitive to drought stress especially during self-pollination where GY can be $53 \%$ less at $75 \%$ silking [64]. Although precipitation from February to May 2020 met the $500 \mathrm{~mm}$ threshold in most of Brazil's Cerrado (Figure 1), monthly rainfall $<20 \mathrm{~mm}$ was more widespread in eastern Matopiba, central Goiás, and northern Mato Grosso (Figure A4, Appendix A). Brazil's Midwest region (which includes Mato Grosso) has had historically more droughts especially over the past two decades compared to 1962-2019 [50]. There have also been increased dry spells even during the wet-season when first-crop (safra) soybeans are grown in Brazil's Midwest region, despite the long-term trend (1940-2010) of more days with rain from October to February [65]. Many of our study's corn hybrids are currently planted by farmers, so additional study is warranted to further clarify climate and management factors limiting farmers realizing the full productive potential of newer corn hybrids as they are more widely adopted.

\subsection{Implications for Sustainable Intensification in Brazil's Cerrado Biome}

\subsubsection{Better Corn Silage Quality and Corn Grain Yield to Increase Sustainable Beef Productivity}

Key elements of sustainable intensification (SI) include increasing agricultural production by increasing crop and livestock yields while improving environmental quality over a diversity of production systems (e.g., conventional, organic, silviculture, etc.). In Brazil, SI can potentially reduce deforestation and natural habitat loss by increasing cropping intensity (e.g., back-to-back cropping) or beef intensification (e.g., semi-intensive feedlots, pasture grain supplementation) via land sparing [66]. Increasing both corn silage quality and corn grain yields can increase beef productivity as Brazil intensifies livestock production. SI of Brazil's beef systems involve transition from extensive grazing for almost 4 years to reducing time to slaughter using (1) semi-intensive feedlots (1.2 years) or (2) grain supplementation in pasture (1.7 to 2.4 years) [67]. Whole-farm modeling of pasture grain supplementation compared to extensive grazing demonstrated lower carbon footprint in southern Brazil [68] along with greater beef productivity and profits as well as lower greenhouse gas emissions and less energy and nitrogen use in Mato Grosso's Cerrado [69]. Feedlots were found in the Amazon and Cerrado biomes in Mato Grosso (MT), Pará, and Rondônia states to be associated with lower on-property deforestation [67]. However, increasing grain use in Brazil's beef industry faces competition from industrial pork and chicken facilities [70].

In our present study, the higher silage quality and corn grain yields (GY) of some corn hybrids suggest improved beef productivity and sustainability if increased corn production from genetic improvement is diverted to beef feedlots and grain supplementation in pasture. For example with corn silage, increasing dry matter digestibility by $6.9 \%$ is associated with an increase in $0.20 \mathrm{~kg} /$ day live weight $(0.17 \mathrm{~kg} /$ day carcass weight $)$ gain in beef [71]. Assuming 126 day average finishing time in Brazil beef feedlots [72] and $430 \mathrm{~kg}$ live weight at slaughter $[69,72]$, our $5.38 \%$ increase in corn silage digestibility from the low to high group (Table 4) suggests a marginal increase of $19.6 \mathrm{~kg}$ live weight (16.7 kg carcass weight) over 126 days of feedlot finishing. Assuming feeding rates $(\mathrm{kg} / \mathrm{head} /$ day) estimated for semi-intensive feedlot corn silage (7.83) and corn grain (2.84) and pasture supplementation corn grain (1.42) used in Mato Grosso (MT) [73] and 126 feeding days for semi-intensive feedlots [72] and 237 feeding days for pasture supplementation [67], required feed for each finished head of beef can be estimated. Each finished beef cattle is estimated to require 0.986 metric tons of corn silage and $357 \mathrm{~kg}$ of corn grain for semi-intensive and $337 \mathrm{~kg}$ of corn grain for pasture supplementation. Using average corn yields from our study, each hectare of corn can semi-intensive feedlot finish about 17 beef cattle or supplement 21 to 34 head of beef in pasture.

Assuming producers in MT can increase corn GY from the 2020 statewide average of $6392 \mathrm{~kg} / \mathrm{hectare}$ (ha) to $8019 \mathrm{~kg} / \mathrm{ha}$ (average of statewide average and our experimental average after subtracting $7.75 \%$ yield loss at harvest [60]), then the additional 8,810,483 metric tons of safrinha corn grain hypothetically produced in MT would be enough to pasture finish 26,143,647 beef cattle, assuming other feed inputs such as soybeans and minerals 
are not limiting. This is $88 \%$ of the total number of beef cattle slaughtered in Brazil in 2020 [74]. Grain supplementation (GS) in Cerrado pasture has been modeled to reduce carbon footprint by $3.01 \mathrm{~kg} \mathrm{CO} 2$ equivalent (eq) $/ \mathrm{kg}$ body weight produced compared to extensive beef grazing [69]. Assuming Brazil can increase pasture-based grain supplementation for 26,143,647 of its cattle, this corresponds to a greenhouse gas emissions reduction of $33,837,722$ metric tons of $\mathrm{CO}_{2}$ eq.

\subsubsection{Higher Corn Grain Yields for Land Sparing, Adaption, and Supporting Crop Diversification}

In addition to being fed to livestock, higher corn grain yields could also buffer against declining corn production in drier Cerrado areas, and against having to rely on farming in areas that are more environmentally and culturally sensitive both recently and potentially in the future. Soybean and corn grain production in Brazil has increased more than fourfold from 1980 to 2016, and unlike soybean production increases which are driven more by area expansion, corn grain production has increased due to the more than doubling of yield over this time [12]. Future increased corn gain yield in Mato Grosso (MT) could compensate for a decrease in double-cropped corn in drier areas such as eastern Matopiba (Figures 5 and A4). Matopiba's agricultural irrigation has put increased pressure on local water supplies and where small-holder diversified local farmers have been displaced for soybean-corn production's "maldevelopment" [75]. Increasing second-crop (safrinha) corn grain yields can land spare, preventing agricultural expansion not just into native habitat [12] but also into more marginal areas in MT with higher slope, lower elevation, and that are drier [76].

Future changes may decrease corn production in Brazil, suggesting that future genetic improvement of corn should focus on adaptation to a changing climate. Recent analysis using 2000-2015 weather data indicates a 6 to $8 \%$ reduction in safrinha corn GY under scenarios of increased Amazon and Cerrado deforestation in MT [77]. Crop modelling with actual climate and projected climate change (2011 to 2050) indicate safrinha corn grain yield losses of $20 \%$ that are statistically significant in the Cerrado in MT and central/southern Goiás states [78]. Modelling "business as usual" climate change (2013-2050; RCP 8.5) shows reductions in areas suitable for back-to-back cropping in Matopiba $(-61 \%)$ and MT/central Brazil ( -17 to $-18 \%$ ) [79]. Since MT state produced nearly half $(46.87 \%)$ of Brazil's safrinha corn in 2020 [13], MT could cover $92 \%$ of potential corn grain losses under RCP 8.5 for Brazilian states in the Cerrado (Figure 2). This is even if MT yields 17-18\% less corn grain due to climate change. However, this assumes corn GY in MT reaches the statewide average yield goal of $8019 \mathrm{~kg} / \mathrm{ha}$ mentioned earlier due to genetic improvement, which may be challenging.

Genetic improvement of corn hybrid grain productivity is needed in more diverse cropping systems where corn grain yields tend to be lower but other soil quality benefits may be realized. Corn in diversified crop-livestock integration (CLI) and crop-livestockforestry integration (CLFI) can take a yield penalty in the short run. Thus, increased corn grain yield due to genetics could make transition to these alternative systems more economically feasible. Corn grain had a yield penalty starting in year 3 of 5 for integrated systems with agro-forestry, due to light reduction during critical periods such as grain filling [80], and this was also affirmed by a recent meta-analysis showing statistically significant lower crop yields in ago-forestry systems ( $n=8$ studies) as part of a larger group of journal articles evaluated for sustainable practices [81].

\section{Conclusions}

Nine of the second-crop (safrinha) corn hybrids we tested showed promising potential with low lignin, high in vitro digestibility, and high grain yields. These hybrids can serve as a basis for improving corn's use in the Cerrado region of Mato Grosso, as they combine lower lignin contents with greater silage in vitro digestibility and higher grain yields. In vitro digestibility is used as a proxy for actual digestibility by large ruminant livestock. Grain yields are typically used for corn silage hybrid selection, and our results 
show that high corn grain yields are correlated with increased in vitro digestibility of silage and lower lignin content. The quality of ensiled forage is more important than grain quality when selecting corn hybrids for production and ensiling. The 20 hybrids we tested did not significantly differ in silage yields, averaging 42.85 metric tons $(t)$ of green matter/hectare (ha) and $13.59 \mathrm{t}$ dry matter/ha. Corn grain yields for 10 high-yielding hybrids averaged $11,425 \mathrm{~kg} /$ ha which was significantly greater than yields for the two lowest yielding hybrids (6974 and $8207 \mathrm{~kg} / \mathrm{ha}$ ). Since precipitation was not limiting in our experiment testing safrinha corn, future research should verify corn silage and corn grain yields and quality for seasons when precipitation during corn pollination and grain filling are inadequate. Increased corn silage quality combined with significantly greater corn grain yield (GY) can support sustainable intensification of livestock finishing. Higher corn GY can land spare, help adapt to lower yields in other areas, and support transition to more diversified cropping systems in Brazil.

Author Contributions: Conceptualization, D.C.d.A. and W.M.d.S.; methodology, A.R.R.M., D.C.d.A. and D.M.S.S.; field experiment and data collection, A.R.R.M., C.V.d.A., D.M.S.S. and L.M.; validation, W.M.d.S.; formal analysis, C.V.d.A. and D.T.P.; investigation, D.C.d.A.; resources, D.C.d.A. and A.K.H.; writing—original draft preparation, D.T.P. and A.K.H.; writing—review and editing, all authors; visualization, R.A.d.O., D.M.S.S. and A.K.H.; supervision, D.C.d.A.; project administration, D.C.d.A.; funding acquisition, D.C.d.A. and W.M.d.S. All authors have read and agreed to the published version of the manuscript.

Funding: This research was funded by Programa Global REDD Early Movers de Mato Grosso (REMMT), Serviço Nacional de Aprendizagem Rural de Mato Grosso (SENAR-MT), and Grupo Bragança Agronegócios (Mato Grosso). The APC was funded by journal article reviews for MDPI journals conducted by A.K.H. from 2020-2021.

Institutional Review Board Statement: Not applicable.

Informed Consent Statement: Informed consent was obtained from all subjects involved in the study.

Data Availability Statement: Five publicly available data sets were analyzed as part of this study. The first data set was daily precipitation data form a weather station $42 \mathrm{~km}$ away from our onfarm experimental site that was downloaded from Agência Nacional de Água (https:/ /www.gov. $\mathrm{br} / \mathrm{ana} / \mathrm{pt}-\mathrm{br}$, accessed on 13 September 2021) over the cropping time frame of our experiment testing corn hybrids. A second daily weather data set was obtained from the Instituto Nacional de Meteorologia (INMET) (https:/ / portal.inmet.gov.br/, accessed on 3 November 2021). A third monthly precipitation spatial data set for February to May 2020 for Brazil was downloaded from the National Aeronautics and Space Administration's Giovanni online data system (https:/ / giovanni. gsfc.nasa.gov/giovanni/, accessed on 26 September 2021). The fourth data set was annual corn production and yield data from Brazilian states with area in the Cerrado biome obtained from Companhia Nacional de Abastecimento (CONAB) (https: / / www.conab.gov.br/info-agro/safras/ serie-historica-das-safra, accessed on 22 August 2021). The fifth data set was monthly and annual beef cattle slaughtered in Brazil in 2020 obtained online from the Instituto Brasileiro de Geografia e Estatística (https://www.ibge.gov.br/estatisticas/economicas/agricultura-e-pecuaria/, accessed on 5 October 2021).

Acknowledgments: The authors would like to thank our cooperators at Fazenda Bragança (Bragança Agronegócios) for allowing use to conduct on-farm field research via our experimental design. Thanks also to both the Universidade Federal de Mato Grosso (UFMT) in Sinop, MT, Brazil as well as Empresa Mato-grossense de Pesquisa, Assistência e Extensão Rural de Mato Grosso (EMPAER-MT) Mato Grosso, in Cuiabá, MT, Brazil for both institutional and logistical support for this research. We would like to thank the undergraduate thesis committee of Diego M.S. Santos for feedback and improving "Behavior of corn hybrids for grain and silage production in the Cerrado Biome," specifically Rogério de Paula Lana, Renato Domiciano Silva Rosado, Clever Briedis, and Daniel Teixeira Pinheiro. Special thanks the SENAR-MT, for the support and incentive for the publication of this study. We also thank two anonymous reviewers for suggested edits and improvements. 
Conflicts of Interest: The authors declare no conflict of interest. Supporting entities had no role in the design of the study; in the collection, analyses, or interpretation of data; in the writing of the manuscript, or in the decision to publish the results.

\section{Appendix A}

Monthly accumulated precipitation (mm) for Brazil for February (Figure A1), March (Figure A2), April (Figure A3), and May (Figure A4):

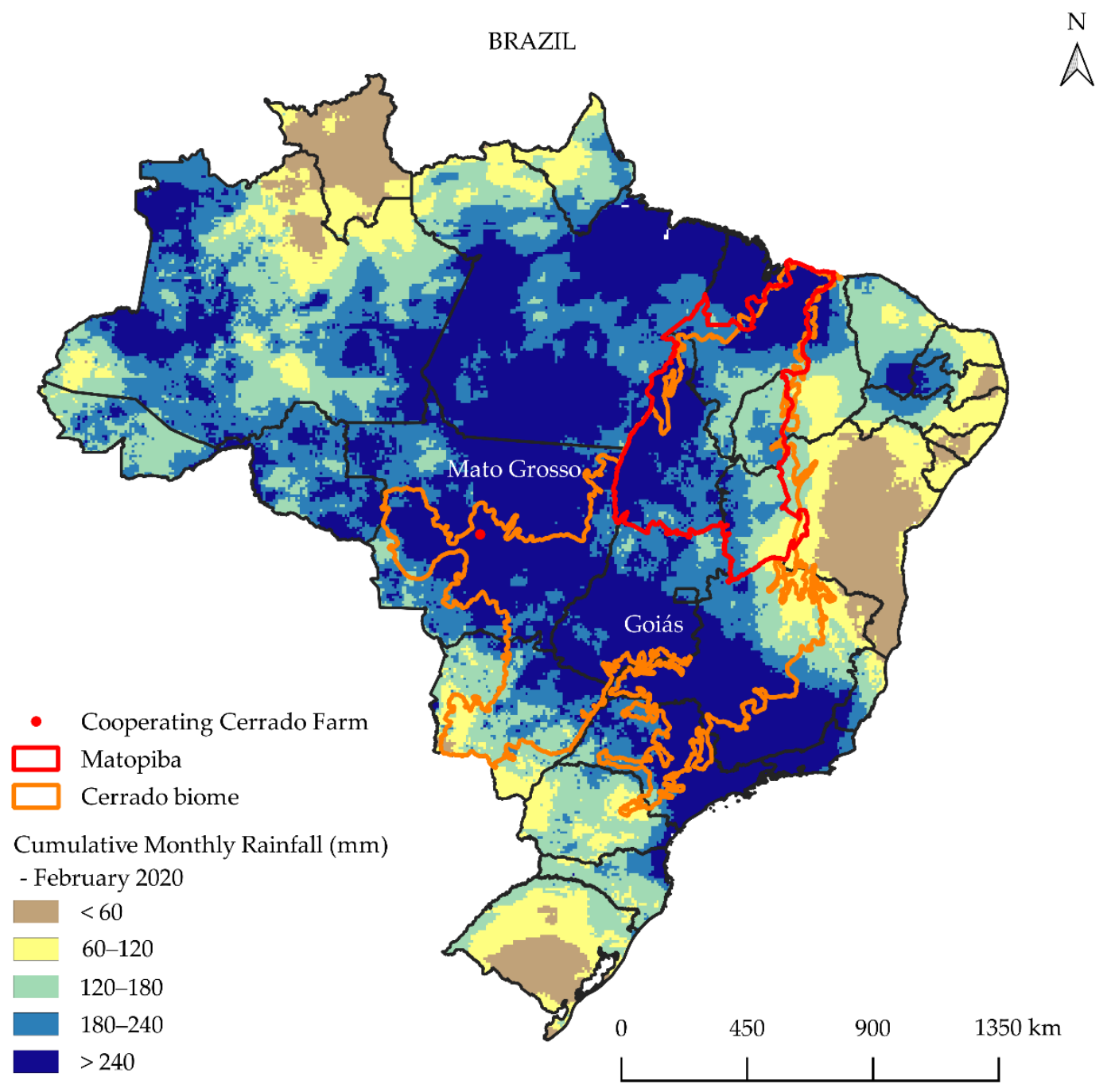

Figure A1. Brazil accumulated precipitation (mm) for February 2020 (60, 120, 180, and 240 mm boundaries). 


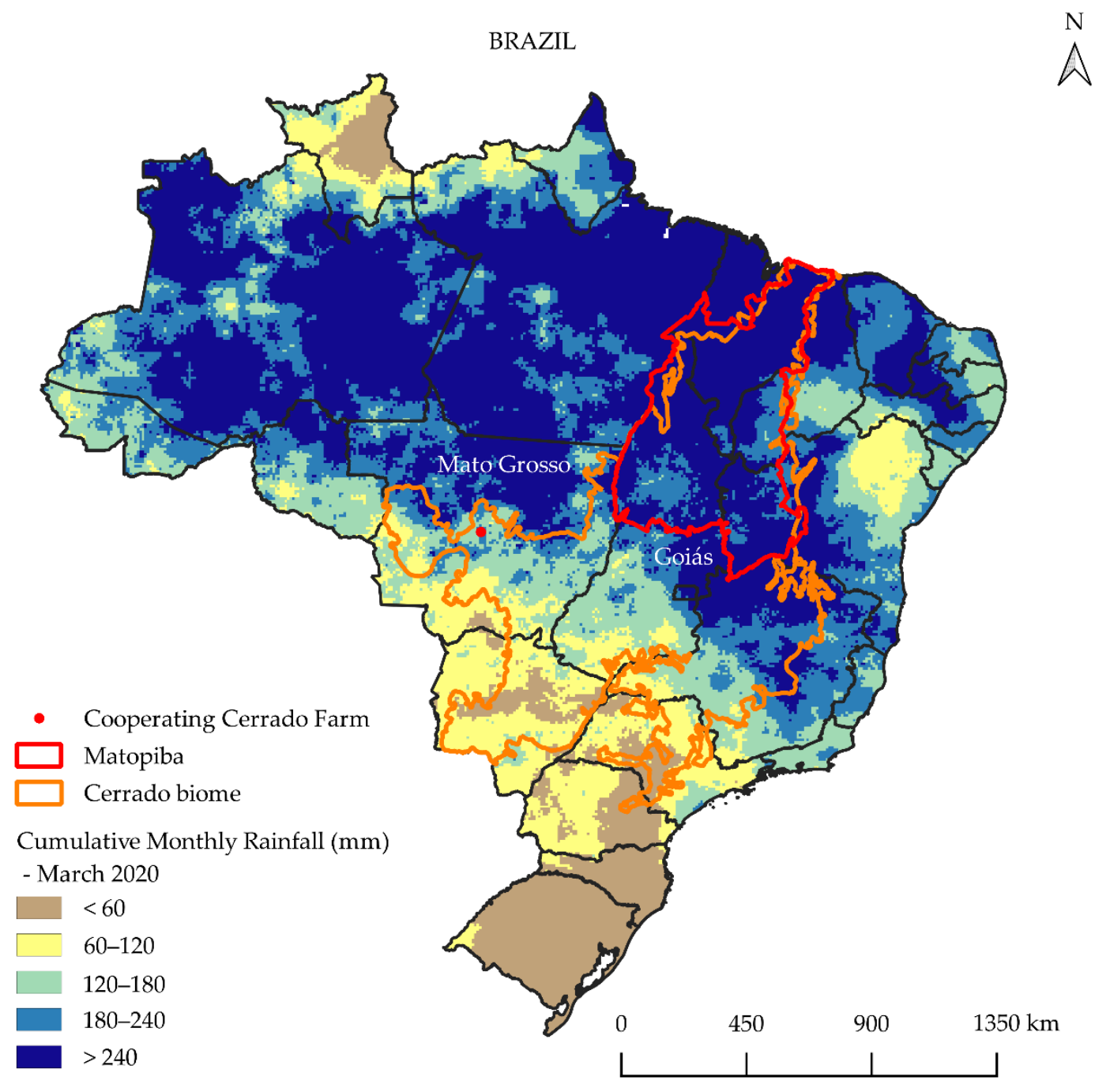

Figure A2. Brazil accumulated precipitation (mm) for March 2020 (60, 120, 180, and 240 mm boundaries). 


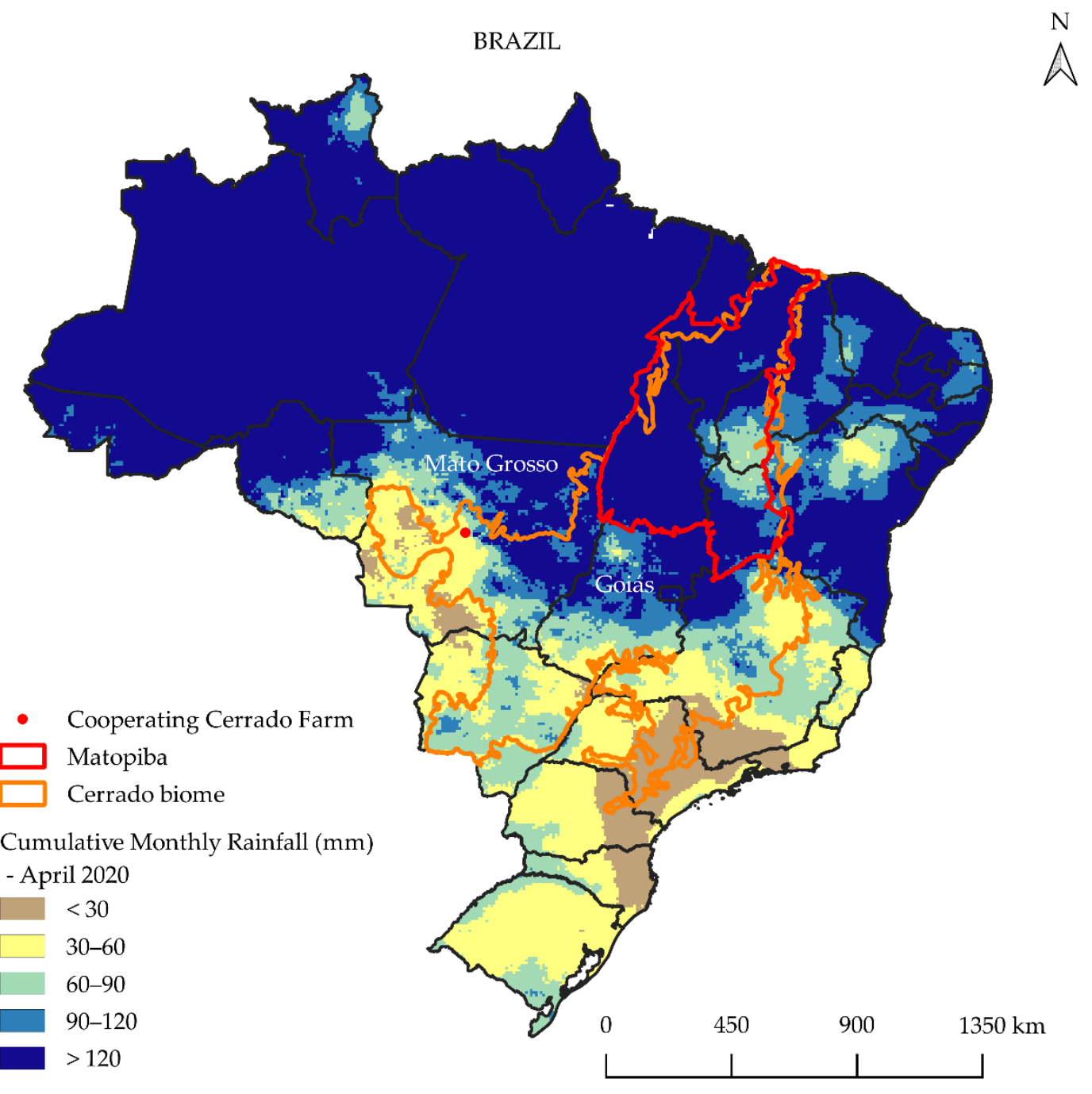

Figure A3. Brazil accumulated precipitation (mm) for April 2020 (30, 60, 90, and $120 \mathrm{~mm}$ boundaries). 


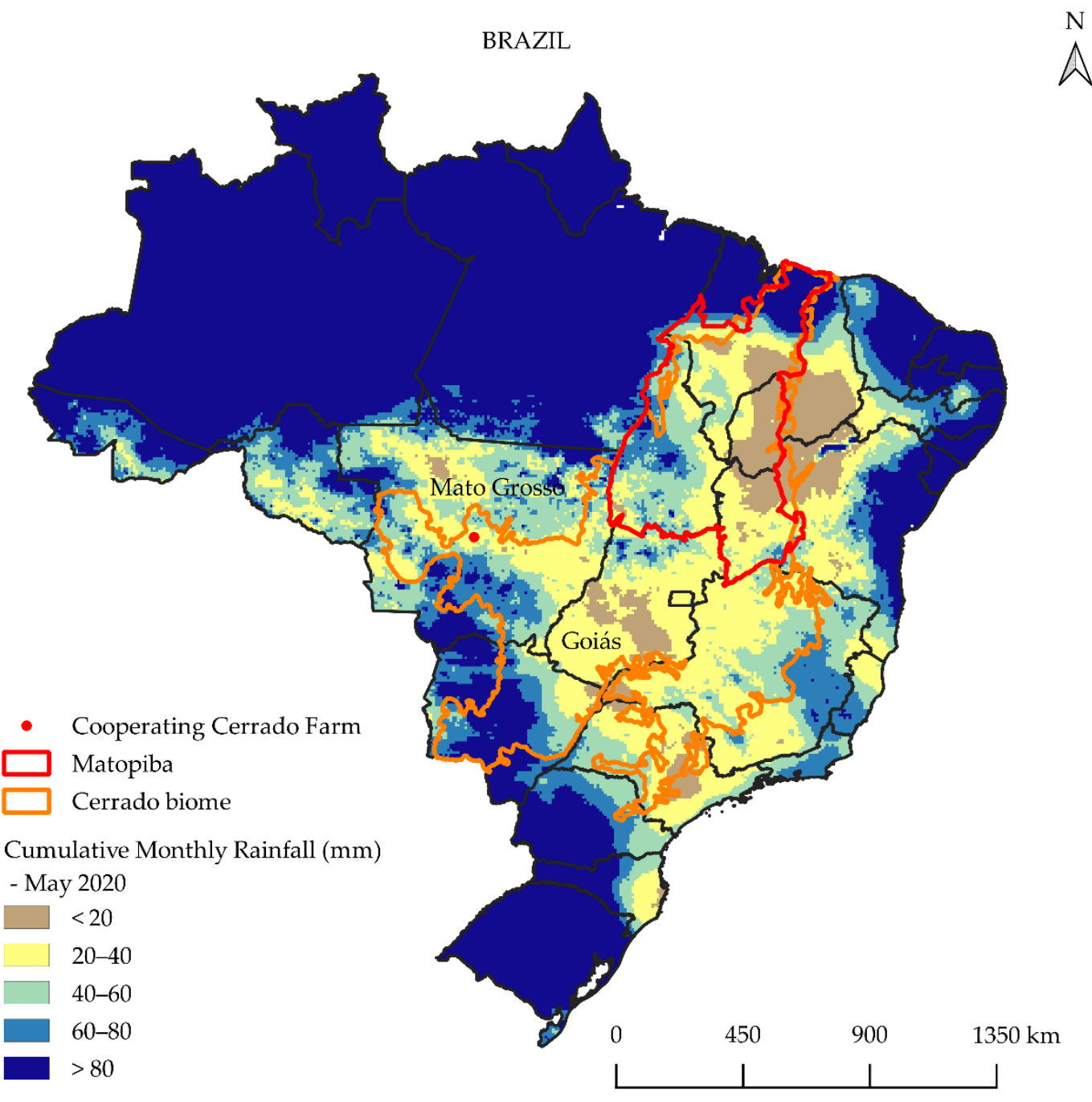

Figure A4. Brazil accumulated precipitation (mm) for May 2020 (20, 40, 60, and $80 \mathrm{~mm}$ boundaries).

\section{References}

1. USDA (United States Department of Agriculture). World Corn Production 2021. Available online: http://www. worldagriculturalproduction.com/crops/corn.aspx (accessed on 10 September 2021).

2. Companhia Nacional de Abastecimento (CONAB). Safra Brasileira de Grãos. 2020. Available online: https://www.conab.gov.br/ ultimas-noticias /3691-producao-de-graos-da-safra-2020-21-segue-como-maior-da-historia-268-9-milhoes-de-toneladas (accessed on 20 August 2021).

3. Bolfe, E.L.; Sano, E.E.; Campos, S.K. Dinâmica Agrícola No Cerrado: Análises e Projeções; Embrapa: Brasília, Brazil, 2020; p. 308. Available online: https://www.embrapa.br/busca-de-publicacoes/- / publicacao/1124106/dinamica-agricola-no-cerradoanalises-e-projecoes (accessed on 14 March 2021).

4. Cruz, J.C.; Gontijo-Neto, M.M.; Albemaz, W.M.; Ferreira, J.J. Qualidade da Silagem de Milho em Função do Teor de Matéria Seca na Ocasião da Colheita; Embrapa Milho e Sorgo: Sete Lagoas, Brazil, 2008; p. 7. Available online: https://www.embrapa.br/buscade-publicacoes /- / publicacao/491771/ qualidade-da-silagem-de-milho-em-funcao-do-teor-de-materia-seca-na-ocasiao-dacolheita (accessed on 11 March 2021).

5. Oliveira, F.C.L.; Jobum, C.C.; Silva, M.S.; Calixto Junior, M.; Bumbieris Junior, V.H.; Roman, J. Produtividade e valor nutricional da silagem de híbridos de milho em diferentes alturas de colheita. Rev. Bras. Zootec. 2011, 40, 720-727. [CrossRef]

6. Pôssas, F.P.; Gonçalves, L.C.; Pereira, L.G.R.; Machado, F.S.; Jayme, D.G.; Rodrigues, J.A.S.; Rodriguez, N.M.; Tomich, T.R. Cinética de fermentação ruminal das silagens de três híbridos de milho comerciais em diferentes estádios de maturação. Arq. Bras. Med. Vet. Zootec. 2015, 67, 159-165. [CrossRef]

7. Massé, D.I.; Jarret, G.; Hassanat, F.; Benchaar, C.; Saady, N.M.C. Effect of increasing levels of corn silage in an alfalfa-based dairy cow diet and of manure management practices on manure fugitive methane emissions. Agric. Ecosyst. Environ. 2016, 221, 109-114. [CrossRef] 
8. Zardin, P.B.; Velho, J.P.; Jobim, C.C.; Alessio, D.R.M.; Haygert-Velho, I.M.P.; Conceição, G.M.; Alemeida, P.S.G. Chemical composition of corn silage produced by scientific studies in Brazil-A meta-analysis. Semin. Ciênc. Agrár. 2017, 38, 503-512. [CrossRef]

9. Ferraretto, L.F.; Shaver, R.D.; Luck, B.D. Silage review: Recent advances and future technologies for whole-plant and fractionated corn silage harvesting. J. Dairy Sci. 2018, 101, 3937-3951. [CrossRef]

10. Figueiredo, A.S.; Pinto, R.J.; Rizzardi, D.A.; Contreras-Soto, R.I.; Matsuzaki, R.A.; Jobum, C.C.; Faria, M.V. Topcrosses in the selection of testers and inbred lines S3 for the yield and bromatological quality of silage maize. Maydica 2019, 63, 14. Available online: https: / /journals-crea.4science.it/index.php/maydica/article/view/1826 (accessed on 15 March 2021).

11. Zalles, V.; Hansen, M.C.; Potapov, P.V.; Stehman, S.V.; Tyukavina, A.; Pickens, A.; Song, X.-P.; Adusei, B.; Okpa, C.; Aguilar, R.; et al. Near doubling of Brazil's intensive row crop area since 2000. Proc. Natl. Acad. Sci. USA 2019, 116, 428-435. [CrossRef]

12. Xu, J.; Gao, J.; de Holanda, H.V.; Rodríguez, L.F.; Caixeta-Filho, J.V.; Zhong, R.; Jiang, H.; Li, H.; Du, Z.; Wang, X.; et al. Double cropping and cropland expansion boost grain production in Brazil. Nat. Food 2021, 2, 264-273. [CrossRef]

13. Companhia Nacional de Abastecimento (CONAB). Série Histórica das Safras 2020 and 2021. Available online: https://www. conab.gov.br/info-agro/safras/serie-historica-das-safras (accessed on 22 August 2021).

14. Spangler, K.R.; Lynch, A.H.; Spera, S.A. Precipitation Drivers of Cropping Frequency in the Brazilian Cerrado: Evidence and Implications for Decision-Making. Weather Clim. Soc. 2017, 9, 201-213. [CrossRef]

15. Soterroni, A.C.; Ramos, F.M.; Mosnier, A.; Fargione, J.; Andrade, P.R.; Baumgarten, L.; Pirker, J.; Obersteiner, M.; Kraxner, F.; Câmara, G.; et al. Expanding the Soy Moratorium to Brazil's Cerrado. Sci. Adv. 2019, 5, eaav7336. [CrossRef]

16. Jaremtchuk, A.R.; Jaremtchuk, C.C.; Baglioli, B.; Medrado, M.T.; Kozlowski, L.A.; Costa, C.; Madeira, H.M.F. Características agronômicas e bromatológicas de vinte genótipos de milho (Zea mays L.) para silagem na região leste paranaense. Acta Sci. Anim. Sci. 2005, 27, 181-188. [CrossRef]

17. Lucci, C.D.S.; Fontolan, V.; Hamilton, T.R.; Klu, R.; Wickbold, V. Corn grain: Corn grain processing for ruminants: Apparent and "in situ" digestibility. Braz. J. Vet. Res. Anim. Sci. 2008, 45, 35-40. [CrossRef]

18. Stella, L.A.; Peripolli, V.; Prates, E.R.; Barcellos, J.O.J. Composição química das silagens de milho e sorgo com inclusão de planta inteira de soja. Bol. Ind. Anim. 2016, 73, 73-79. [CrossRef]

19. Holt, M.S.; Yanf, S.Y.; Creech, J.E.; Eun, J.S.; Young, A. In situ ruminal degradation kinetics of corn silage hybrids harvested prior to or at maturity in dry and lactating dairy cow. J. Anim. Plant Sci. 2016, 26, 46-53. Available online: http://www.thejaps.org.pk/ docs/v-26-01/07.pdf (accessed on 1 April 2021).

20. Baghdadi, A.; Halim, R.A.; Ghasemzadeh, A.; Ramlan, M.F.; Sakimin, S.Z. Impact of organic and inorganic fertilizers on the yield and quality of silage corn intercropped with soybean. PeerJ-Life Environ. 2018, 6, e5280. [CrossRef]

21. Ali, W.; Nadeem, M.; Ashiq, W.; Zaeem, M.; Gilani, S.S.M.; Rajabi-Khamseh, S.; Pham, T.H.; Kavanagh, V.; Thomas, R.; Cheema, $\mathrm{M}$. The effects of organic and inorganic phosphorus amendments on the biochemical attributes and active microbial population of agriculture podzols following silage corn cultivation in boreal climate. Sci. Rep. 2019, 9, 17297. [CrossRef]

22. Rezende, R.P.; Golin, H.O.; Abreu, V.L.S.; Theodoro, G.F.; Franco, G.L.; Brumatii, R.C.; Fernandes, P.B.; Bento, A.L.L.; Rocha, R.F.A.T. Does intercropping maize with forage sorghum effect biomass yield, silage bromatological quality and economic viability? Res. Soc. Dev. 2020, 9, e46942818. [CrossRef]

23. Nazli, M.H.; Halim, R.A.; Abdullah, A.M.; Hussin, G.; Samsudin, A.A. Potential of four corn varieties at different harvest stages for silage production in Malaysia. Asian-Australas. J. Anim. Sci. 2019, 32, 224-232. [CrossRef]

24. Hallauer, A.R. History, contribution, and future of quantitative genetics in plant breeding: Lessons from maize. Crop Sci. 2007, 47, S-4-S-19. [CrossRef]

25. Klein, J.L.; Viana, A.F.P.; Martini, P.M.; Adams, S.M.; Guzatto, C.; Bona, R.D.A.; Rodrigues, L.S.; Alves-Filho, D.C.; Brondani, I.L. Desempenho produtivo de híbridos de milho para a produção de silagem da planta inteira. Rev. Bras. Milho Sorgo 2018, 17, 101-110. [CrossRef]

26. Moraes, S.D.; Jobim, C.C.; Silva, M.S.; Marquardt, F.I. Produção e composição química de híbridos de sorgo e de milho para silagem. Rev. Bras. Saúde Prod. Anim. 2013, 14, 624-634. [CrossRef]

27. Crevelari, J.A.; Durães, N.N.L.; Gonçalves, G.M.B.; Júnior, J.A.F.; Gonçalves, V.M.L.; Santanna, C.Q.S.S.; Azevedo, F.H.V.; Pereira, M.G. Phenotypic correlations and path analysis between morphoagronomic and bromatological traits in corn hybrids for silage production. Aust. J. Crop Sci. 2020, 14, 1905-1912. [CrossRef]

28. Eritro, B.T.; Zeleke, H.; Friesen, D.; Blummel, M.; Twumasi-Afriyie, S. Relationship between the performance of parental inbred lines and hybrids for food-feed traits in maize (Zea mays L.) in Ethiopia. Field Crop Res. 2013, 153, 86-93. [CrossRef]

29. Zystro, J.; Peters, T.E.; Miller, K.M.; Tracy, W.F. Inbred and hybrid sweet corn genotype performance in diverse organic environments. Crop Sci. 2021, 61, 2280-2293. [CrossRef]

30. National Aeronautics and Space Administration (NASA). Global Precipitation Measurement IMERG Final Precipitation L3 version 6 (GPM_3IMERGM 06), Giovanni Online Data System. Available online: https:/ /giovanni.gsfc.nasa.gov/giovanni/ \#service=TmAvMp\&starttime=\&endtime=\&dataKeyword=IMERGM (accessed on 26 September 2021).

31. Agência Nacional de Água (ANA). Sistema de Informações Hidrológicas. 2020. Available online: https://www.gov.br/ana/pt-br (accessed on 13 September 2021).

32. Instituto Nacional de Meteorologia (INMET). Banco de Dados Meteorológicos do INMET. 2021. Available online: https: / / portal.inmet.gov.br/ (accessed on 3 November 2021). 
33. Jolliffe, I.T.; Cadima, J. Principal component analysis: A review and recent developments. Philos. Trans. R. Soc. Math. Phys. Eng. Sci. 2016, 374, 20150202. [CrossRef] [PubMed]

34. Kassambara, A.; Mundt, F. Package 'Factoextra': Extract and Visualize the Results for Multivariate Data Analyses; Version 1.0.3 2016. Available online: https://cran.microsoft.com/snapshot/2016-11-30/web/packages/factoextra/factoextra.pdf (accessed on 25 March 2021).

35. Velho, J.P.; Mühlbach, P.R.F.; Nörnberg, J.L.; Velho, I.M.P.H.; Genro, T.C.M.; Kessler, J.D. Composição bromatológica de silagens de milho produzidas com diferentes densidades de compactação. Rev. Bras. Zootec. 2007, 36, 1532-1538. [CrossRef]

36. Liu, Q.; Luo, L.; Zheng, L. Lignins: Biosynthesis and Biological Functions in Plants. Int. J. Mol. Sci. 2018, 19, 335. [CrossRef]

37. Khan, M.U.; Ahring, B.K. Lignin degradation under anaerobic digestion: Influence of lignin modifications-A review. Biomass Bioenergy 2019, 128, 105325. [CrossRef]

38. Bonawitz, N.D.; Chapple, C. The genetics of lignin biosynthesis: Connecting genotype to phenotype. Ann. Rev. Genet. 2010, 44, 337-363. [CrossRef] [PubMed]

39. Raffrenato, E.; Fievisohn, R.; Cotanch, K.W.; Grant, R.J.; Chase, L.E.; Van Amburgh, M.E. Effect of lignin linkages with other plant cell wall components on in vitro and in vivo neutral detergent fiber digestibility and rate of digestion of grass forages. J. Dairy Sci. 2017, 100, 8119-8131. [CrossRef]

40. Mendes, M.C.; Von Pinho, R.G.; Pereira, M.N.; Faria Filho, E.M.; Ssouza Filho, A.X. Avaliação de híbridos de milho obtidos do cruzamento entre linhagens com diferentes níveis de degradabilidade da matéria seca. Bragantia 2008, 67, 285-297. [CrossRef]

41. Crevelari, J.A.; Durães, N.N.L.; Santos, P.R.; Azevedo, F.H.V.; Bendia, L.C.R.; Preisigke, S.C.; Gonçalves, G.M.B.; Ferreira-Junior, J.A.; Pereira, M.G. Canonical correlation for morphoagronomic and bromatological traits in silage corn genotypes. Bragantia 2019, 78, 337-349. [CrossRef]

42. Pinho, R.G.V.; Vasconcelos, R.C.; Borges, I.D.; Resende, A.V. Produtividade e qualidade da silagem de milho e sorgo em função da época de semeadura. Bragantia 2007, 66, 235-245. [CrossRef]

43. Costa, N.R.; Andreotti, M.; Crusciol, C.A.C.; Lima, C.G.R.; Castilhos, A.M.; Souza, D.M.; Bonini, C.S.B.; Pariz, C.M. Yield and nutritive value of the silage of corn intercropped with tropical perennial grasses. Pesqui. Agropecu. Bras. Bras. 2017, 52, 63-73. [CrossRef]

44. Zopollatto, M.; Nussio, L.G.; Paziani, S.F.; Ribeiro, J.L.; Sarturi, J.O.; Mourão, G.B. Relações biométricas entre o estádio de maturação e a produtividade de híbridos de milho para produção de silagem. R. Bras. Zootec. 2009, 38, 256-264. [CrossRef]

45. Sanches, A.C.; Maffei, R.G.; de Jesus, F.L.F.; Mendonça, F.C.; Souza, D.P. Produtividade de Híbridos de Milho Irrigado Para Silagem Sob doses Nitrogenadas. In Proceedings of the IV Inovagri International Meeting, Fortaleza, Brazil, 2-6 October 2017. [CrossRef]

46. Bastista, V.V.; Adami, P.F.; Salomão, E.C.; Link, L.; Oligini, K.F.; Giacomel, C.L. Produtividade e qualidade bromatológica de silagem de milho em monocultivo e consorciado. Rev. Cult. Saber 2018, 11, 115-128. Available online: https://www.fag.edu.br/ upload/revista/cultivando_o_saber/5c06b8a77c756.pdf (accessed on 1 October 2021).

47. Gomes, M.S.; Pinho, R.G.V.; Ramalho, M.A.P.; Ferreira, D.V.; Brito, A.H. Variabilidade genética em linhagens de milho nas características relacionadas com a produtividade de silagem. Pesqui. Agropecu. Bras. 2004, 39, 879-885. [CrossRef]

48. Domingues, A.N.; Abreu, J.G.; Cabral, L.S.; Galati, R.L.; Oliveira, M.A.; Reis, R.H.P. Nutrition value of silage from corn hybrids in the State of Mato Grosso, Brazil. Acta Sci. Anim. Sci. 2012, 34, 117-122. [CrossRef]

49. Frei, M. Lignin: Characterization of a Multifaceted Crop Component. Sci. World J. 2013, 436527, 25. [CrossRef] [PubMed]

50. Cunha, A.P.M.A.; Zeri, M.; Leal, K.D.; Costa, L.; Cuartas, L.A.; Marengo, J.A.; Tomasella, J.; Vieira, R.M.; Barbosa, A.A.; Cunningham, C.; et al. Extreme Drought Events over Brazil from 2011 to 2019. Atmosphere 2019, 10, 642. [CrossRef]

51. Oligini, K.F.; Salomão, E.C.; Batista, V.V.; Link, L.; Adami, P.F.; Sartor, L.R. Produtividade de milho consorciado com espécies forrageiras no sudoeste do Paraná. Rev. Agrar. 2019, 12, 434-442. Available online: https://ojs.ufgd.edu.br/index.php/agrarian/ article/view / 8705 (accessed on 3 October 2021).

52. Bettio, C.S.; Ganascini, D.; Wunsh, C.A.; Renosto, L.; Maggi, M.F.; Gurgacz, F. Produtividade do milho (Zea mays L.) com diferentes arranjos populacionais em linhas simples e duplas. Acta Iguazu 2017, 6, 44-51. Available online: https:/ / e-revista.unioeste.br/ index.php/actaiguazu/article/view/17706 (accessed on 4 October 2021).

53. Lima, N.G.; Mota, J.H.; Resende, G.M.; Yuri, J.E.; Teixeira, I.R. Avaliação de cultivares de milho para consumo in natura em Jataí-GO. Cad. Ciênc. Agrár. 2019, 11,1-7. Available online: https://periodicos.ufmg.br/index.php/ccaufmg/article/view/15963 (accessed on 2 October 2021). [CrossRef]

54. Peron, G.C.; Pinho, R.G.V.; Bernardo Junior, L.A.Y.; Souza, V.F.; Pereira, F.C.; Vieira Junior, I.C.; Balestre, M.; Cardoso, D.A.D.B. Influência de formas de adubação de semeadura na produtividade de grãos de híbridos de milho. Rev. Bras. Milho Sorgo 2019, 18, 88-98. [CrossRef]

55. Simão, E.P.; Resende, A.V.; Neto, M.M.G.; Silva, A.F.; Godinho, V.P.C.; Galvão, J.C.C.; Borghi, E.; Oliveira, A.C.; Giehl, J. Nitrogen fertilization in off-season corn crop in different Brazilian Cerrado environments. Pesqui. Agropec. Bras. 2020, 55, e01551. [CrossRef]

56. Makino, P.A.; Ceccon, G.; Fachinelli, R. Produtividade e teor de nutrientes em populações de milho safrinha solteiro e consorciado com braquiária. Rev. Bras. Milho Sorgo 2019, 18, 206-220. [CrossRef]

57. Ceccon, G.; Staut, L.A.; Sagrilo, E.; Machado, L.A.Z.; Nunes, D.P.; Alves, V.B. Legume and Forage Species Sole or Intercropped with Corn in Soybean-Corn Succession in Midwestern Brazil. Rev. Bras. Ciênc. Solo 2013, 37, 204-212. [CrossRef] 
58. Carnevalli, R.A.; Santos, E.B.C.; Abreu, J.G.; Garcia, L.F.; Coletti, A.J.; Giustina, C.D.; Peixoto, W.M.; Herrera, L.D.S.; Rodrigues, J.A. Production of Maize Silage is Possible in Integrated Systems with Arboreal Component. J. Exp. Agric. Int. 2019, 39, 1-9. [CrossRef]

59. Fiorini, I.V.; Pereira, C.S.; Pereira, H.D.; Medeiros, A.L.; Pires, L.P.M. Produtividade e seus componentes segundo épocas de semeadura de milho safrinha no Norte de Mato Grosso. J. Bioenergy Food Sci. 2018, 5, 54-65. [CrossRef]

60. Loureiro, D.R.; Fernandes, H.C.; Teixeira, M.M.; Leite, D.M.; Costa, M.M. Quantitative losses in mechanized harvesting corn crop in small footprint and conventional. Semin. Ciênc. Agrár. 2012, 33, 565-574. [CrossRef]

61. Maldaner, L.J.; Horing, K.; Schneider, J.F.; Frigo, J.P.; de Azevedo, K.D.; Grzesiuck, A.E. Exigência Agroclimática da Cultura do Milho (Zea mays). Rev. Bras. Energ. Renov. 2014, 3, 13-23. [CrossRef]

62. Junior, E.G.C. Necessidades Hídricas Das Culturas Milho e Feijãocaupi Influenciadas Pelas Mudanças Climáticas No Semiárido Nordestino. Ph.D. Thesis, Universidade Federal Rural do Semi-Árido, Mossoró, Brazil, 23 September 2015; p. 82. Available online: https:/ / repositorio.ufersa.edu.br/bitstream/tede/414/1/EdmilsonGCJ_TESE.pdf (accessed on 25 September 2021).

63. Francisco, P.R.M.; Santos, D.; Guimarães, C.L.; Araujo, S.R.D.; Oliveira, F.P.d. Aptidão Climática do Milho (Zea mays L.) para o Estado da Paraíba. Rev. Geogr. (Recife) 2017, 34, 290-305. [CrossRef]

64. Claassen, M.M.; Shaw, R.H. Water Deficit Effects on Corn. II. Grain Components. Agron. J. 1970, 62, 652-655. [CrossRef]

65. Carvalho, J.R.P.d.; Assad, E.D.; Evangelista, S.R.M.; Pinto, H.d.S. Estimation of dry spells in three Brazilian regions-Analysis of extremes. Atmos. Res. 2013, 132-133, 12-21. [CrossRef]

66. Garnett, T.; Appleby, M.C.; Balmford, A.; Bateman, I.J.; Benton, T.G.; Bloomer, P.; Burlingame, B.; Dawkins, M.; Dolan, L.; Fraser, D.; et al. Sustainable Intensification in Agriculture: Premises and Policies. Science 2013, 341, 33-34. [CrossRef] [PubMed]

67. Vale, P.; Gibbs, H.; Vale, R.; Christie, M.; Florence, E.; Munger, J.; Sabaini, D. The Expansion of Intensirve Beef Farming to the Brazilian Amazon. Glob. Environ. Chang. 2019, 57, 101922. [CrossRef]

68. Pereira, C.H.; Patino, H.O.; Hoshide, A.K.; Abreu, D.C.; Alan Rotz, C.; Nabinger, C. Grazing supplementation and crop diversification benefits for southern Brazil beef: A case study. Agric. Syst. 2018, 162, 1-9. [CrossRef]

69. Molossi, L.; Hoshide, A.K.; Pedrosa, L.M.; Oliveira, A.S.; Abreu, D.C. Improve pasture or feed grain?: Greenhouse gas emissions, profitability, and resource use for Nelore beef cattle in Brazil's Cerrado and Amazon biomes. Animals 2020, 10, 1386. [CrossRef]

70. Garrett, R.D.; Koh, I.; Lambin, E.F.; de Waroux, Y.P.; Kastens, J.H.; Brown, J.C. Intensification in agriculture-forest frontiers: Land use responses to development and convervation policies in Brazil. Glob. Environ. Chang. 2018, 53, 233-243. [CrossRef]

71. Keady, T. The Effects of Silage Digestibility on the Performance of Beef Cattle, Dairy Cows, Pregnant Ewes and Finishing Lambs; Teagasc, Animal and Grassland Research and Innovation Centre, Mellows Campus: Athenry, County Galway, Ireland, 2012; p. 10. Available online: https://www.teagasc.ie/media/website/publications/2012/The_effects_of_silage_digestibility_on_animal_ performance.pdf (accessed on 19 September 2021).

72. Ferraz, J.B.S.; de Felício, P.E. Production systems-An example from Brazil. Meat Sci. 2010, 84, 238-243. [CrossRef] [PubMed]

73. Pedrosa, L.M.; Hoshide, A.K.; Abreu, D.C.; Molossi, L.; Couto, E.G. Financial transition and costs of sustainable agricultural intensification practices on a beef cattle and crop farm in Brazil's Amazon. Renew. Agric. Food Syst. 2019, 36, 26-37. [CrossRef]

74. Instituto Brasileiro de Geografia e Estatística (IBGE). Pesquisa Trimestral do Abate de Animais. 2021. Available online: https:/ / www.ibge.gov.br/estatisticas/economicas / agricultura-e-pecuaria/9203-pesquisas-trimestrais-do-abate-de-animais. htmledicao $=20755 \& \mathrm{t}=$ downloads (accessed on 5 October 2021).

75. Lopes, G.R.; Lima, M.G.B.; doe Reis, T.N.P. Maldevelopment revisited: Inclusiveness and social impacts of soy expansion over Brazil's Cerrado in Matopiba. World Dev. 2021, 139, 105316. [CrossRef]

76. Spera, S.A.; Cohn, A.S.; VanWey, L.K.; Mustard, J.F.; Rudorff, B.F.; Risso, J.; Adami, M. Recent cropping frequency, expansion, and abandonment in Mato Grosso, Brazil had selective land characteristics. Environ. Res. Lett. 2014, 9, 064010. [CrossRef]

77. Spera, S.A.; Winter, J.M.; Partridge, T.F. Brazilian Maize Yields Negatively Affected by Land Clearing. Nat. Sustain. 2020, 3 , 845-852. [CrossRef]

78. Brumatti, L.M.; Pires, G.F.; Santos, A.B. Challenges to the Adaptation of Double Cropping Agricultural Systems in Brazil under Changes in Climate and Land Cover. Atmosphere 2020, 11, 1310. [CrossRef]

79. Abrahão, G.M.; Costa, M.H. Evolution of rain and photoperiod limitations on the soybean growing season in Brazil: The rise (and possible fall) of double-cropping systems. Agric. For. Meteorol. 2018, 256-257, 32-45. [CrossRef]

80. Magalhães, C.A.S.; Pedreira, B.C.; Tonini, H.; Farias Neto, A.L. Crop, livestock and forestry performance assessment under different production systems in the north of Matro Grosso, Brazil. Agrofor. Syst. 2019, 93, 2085-2096. [CrossRef]

81. Bueno, R.S.; Marchetti, L.; Cocozza, C.; Marchetti, M.; Salbitano, F. Could cattle ranching and soybean cultivation be sustainable? A systematic review and a meta-analysis for the Amazon. iForest-Biogeosci. For. 2021, 14, 285-298. [CrossRef] 